\title{
In Vitro Selective Antibacterial and Antiproliferative Effects of Ethanolic Extracts from Cambodian and Philippine Plants Used in Folk Medicine for Diarrhea Treatment
}

\section{OPEN ACCESS}

Edited by:

Alessandra Durazzo,

Council for Agricultural Research and

Economics, Italy

Reviewed by:

Abdul Majeed,

Bahauddin Zakariya University,

Pakistan

Jamuna Aswathanarayan, JSS Academy of Higher Education and Research, India

Folorunso Oludayo Fasina, University of Pretoria, South Africa

Hasanga Rathnayake,

University of Ruhuna, Sri Lanka

${ }^{*}$ Correspondence:

Ladislav Kokoska kokoska@ftz.czu.cz

Specialty section:

This article was submitted to Ethnopharmacology, a section of the journal

Frontiers in Pharmacology

Received: 24 July 2021 Accepted: 08 October 2021 Published: 26 November 2021

Citation:

Kudera T, Fiserova B, Korytakova M,

Doskocil I, Salmonova H, Tulin EE, Nguon S, Bande MM and Kokoska L (2021) In Vitro Selective Antibacterial and Antiproliferative Effects of Ethanolic Extracts from Cambodian and Philippine Plants Used in Folk Medicine for Diarrhea Treatment.

Front. Pharmacol. 12:746808 doi: 10.3389/fphar.2021.746808
Tomas Kudera ${ }^{1}$, Barbora Fiserova ${ }^{1}$, Marie Korytakova ${ }^{1}$, Ivo Doskocil $^{2}$, Hana Salmonova ${ }^{2}$, Edgardo E. Tulin ${ }^{3}$, Samnang Nguon ${ }^{4}$, Marlito M. Bande ${ }^{5}$ and Ladislav Kokoska ${ }^{1 *}$

${ }^{1}$ Laboratory of Ethnobotany and Ethnopharmacology, Department of Crop Sciences and Agroforestry, Faculty of Tropical AgriSciences, Czech University of Life Sciences Prague, Prague, Czechia, ${ }^{2}$ Faculty of Agrobiology, Food and Natural Resources, Department of Microbiology, Nutrition and Dietetics, Czech University of Life Sciences Prague, Prague, Czechia, ${ }^{3}$ PhilRootcrops, Visayas State University, Baybay, Philippines, ${ }^{4}$ Graduate School, Royal University of Agriculture, Phnom Penh, Cambodia, ${ }^{5}$ Institute of Tropical Ecology and Environmental Management, Visayas State University, Baybay, Philippines

Bacterial diarrhea remains a global health problem, especially in developing tropical countries. Moreover, dysbiosis caused by diarrheagenic bacteria and inappropriate antimicrobial treatment has been associated with intestinal carcinogenesis. Despite the rich tradition of the use of herbs for the treatment of gastrointestinal disorders in Cambodian and Philippine folk medicine, many of them have not yet been systematically studied for their in vitro selective inhibitory effects on intestinal bacteria and cells. In the present study, in vitro inhibitory activities of 35 ethanolic extracts derived from 32 Cambodian and Philippine medicinal plants were determined by broth microdilution method against 12 pathogenic bacteria. Furthermore, cytotoxicity against intestinal cancer cells (Caco-2 and HT-29) using thiazolyl blue tetrazolium bromide cytotoxicity assay and safety to six beneficial intestinal bacteria (bifidobacteria and lactobacilli) and intestinal normal cells (FHs $74 \mathrm{Int}$ ) were determined for the antimicrobially active extracts. Selectivity indices (SIs) were calculated among the averages of minimum inhibitory concentrations (MICs), half-maximal inhibitory concentrations $\left(\mathrm{IC}_{50}\right)$, and $80 \%$ inhibitory concentrations of proliferation $\left(\mathrm{IC}_{80}\right)$ for each type of the tested agents. The extracts of Artocarpus blancoi (Elmer) Merr. (Moraceae), Ancistrocladus tectorius (Lour.) Merr. (Ancistrocladaceae), and Pentacme siamensis (Miq.) Kurz (Dipterocarpaceae) produced significant growth-inhibitory effects (MICs = 32-512 $\mathrm{\mu g} / \mathrm{ml}$ ) against intestinal pathogenic bacteria at the concentrations nontoxic to normal intestinal cells $\left(I_{80}\right.$ values $>512 \mu \mathrm{g} / \mathrm{ml}$; Sls $\left.=0.11-0.2\right)$. Moreover, the extract of $P$. siamensis (Miq.) Kurz was relatively safe to beneficial bacteria (MICs $\geq 512 \mu \mathrm{g} / \mathrm{ml} ; \mathrm{SI}=0.1$ ), and together with $A$. blancoi (Elmer) Merr., they selectively inhibited intestinal cancer cells $\left(I_{50}\right.$ values $\geq 51.98 \pm 19.79 \mu \mathrm{g} / \mathrm{ml}$; Sls $=0.3$ and 0.6$)$. Finally, a strong selective antiproliferative effect on cancer cells $\left(\mathrm{IC}_{50}\right.$ values $37.89 \pm 2.68$ to $130.89 \pm 13.99 \mu \mathrm{g} /$ $\mathrm{ml}$; Sls $=0.5$ ) was exerted by Ehretia microphylla Lam. (Boraginaceae), Lagerstroemia cochinchinensis Pierre ex Gagnep. (Lythraceae), and Melastoma saigonense (Kuntze) 
Merr. (Melastomataceae) (leaves with flower buds). The results suggest that the abovementioned species are promising materials for the development of new selective antibacterial and antiproliferative agents for the treatment of infectious diarrhea and associated intestinal cancer diseases. However, further research is needed regarding the isolation and identification of their active constituents.

Keywords: diarrhea, Cambodia, Philippines, medicinal plant, antibacterial, anticancer

\section{INTRODUCTION}

According to the latest data of the World Health Organization, infectious diarrhea is still the third leading cause of death among all communicable diseases worldwide, especially affecting underfive children in developing countries (World Health Organization, 2020a). Moreover, common risk factors associated with these gastrointestinal infections, such as inappropriate changes in the host-gut microbiome (Sun et al., 2018), have been considered as a crucial precondition for several noncommunicable intestinal diseases, including colorectal cancer, which is the third leading cause of cancer death globally (Taddese et al., 2020). The developed countries are at the highest risk, but the incidence of gastrointestinal cancers in developing nations is steadily increasing (Rawla et al., 2019). Infectious and toxigenic strains of Bacillus cereus, Campylobacter jejuni, Clostridium difficile, Clostridium perfringens, Enterococcus faecalis, Escherichia coli, Listeria monocytogenes, Salmonella spp., Shigella spp., Vibrio cholerae, Vibrio parahaemolyticus, and Yersinia enterocolitica are the major causes of bacterial diarrhea (Casburn-Jones, 2004). Among these, Enterococcus spp., Escherichia spp., and Shigella spp. were previously observed to be richer in the fecal microbiota of patients with colorectal cancer (Xu and Jiang, 2017).

Despite the advantages of treatment utilizing antibiotic agents, disruption of the gut microbiota is usually considered as one of the negative consequences of their use in infectious diarrhea (Francino, 2016). Moreover, the antimicrobial resistance rate among diarrheagenic bacteria recovered from human patients has significantly increased, especially in developing countries (Meng et al., 2011; World Health Organization, 2020b). Therefore, it is important to seek new sources of efficient antimicrobial agents against which the infectious bacteria are less prone to develop resistance (Sibanda and Okoh, 2007). Additionally, agents that are highly selective, thus less disruptive for human microbial ecology, should be preferred (Garrett, 2019). Therefore, an investigation on the in vitro antimicrobial effects of promising candidates is recommended to involve both representatives of diarrheagenic and probiotic bacteria. The most common bacteria recognized to date as probiotics are Lactobacillus spp. and Bifidobacterium spp., belonging to the dominant bacterial phyla that can be found in human intestines (Behnsen et al., 2013). Although it is a simplified representation of beneficial gut microbiota, the counterscreen of in vitro inhibitory activities on gut commensals appears to be an effective way to avoid unnecessarily promiscuous agents (Gavrish et al., 2014).
Additionally, assessment of interactions with intestinal epithelial cells and toxicity profiles is another important factor for the evaluation of antibacterial agents, which target the intestinal site (Maher and McClean, 2006). To lower the potential toxic responses of intestinal epithelial cells, the use of antibacterial agents with mechanisms enabling toxicity to be prokaryotic but not eukaryotic cells, such as in the case of the antibiotic ceftriaxone, should be prioritized (Neftel and Hübscher, 1987). However, the antiproliferative activity can be acknowledged in cases where the immune responses caused by ongoing intestinal infection and dysbiosis have already promoted the carcinogenesis of epithelial cells. Initially, colorectal cancer usually has an oligosymptomatic characteristic; thus, many cases are diagnosed only at advanced stages, at which stage the therapeutic outcomes are poor (Rogowski and Sulzyc-Bielicka, 2016). Antibacterial agents able to eliminate diarrheagenic pathogens and having the additional selective antiproliferative properties could potentially help to prevent progression of yet not diagnosed intestinal cancers. The use of antibiotics-such as quinolones and tetracyclines, which are both utilized in diarrheal infections-as anticancer drugs has been previously suggested (Onoda et al., 2005; Batalha et al., 2016).

Plant-derived products provide novel chemical scaffolds for anti-infective drugs and leads that have chemically been modified and developed as antimicrobial agents. Several over-the-counter pharmaceuticals, dietary supplements, and herbal medicines recommended for the support and maintenance of gastrointestinal health, containing antibacterially active plant extracts and derivatives of their constituents, are already available at the international market. The benzylisoquinoline alkaloid berberine (e.g., Hydrastis canadensis L. [Ranunculaceae]); simple phenol bismuth subsalicylate, the analog of salicylic acid derived from salicin (Salix alba L. [Salicaceae]) (Kokoska et al., 2019); and picrosides, an iridoid glycoside of Picrorhiza kurroa Royle ex Benth. (Plantaginaceae), are some examples (Rathee et al., 2016). The in vitro selective antibacterial effects of plant-derived products have also been reported. For example, Chan et al. (2018) reported that the phenolic-rich extracts from various dietary spices and medicinal herbs (Cinnamomum burmannii Nees and T.Nees] Blume [Lauraceae], Cinnamomum cassia [L.] J.Presl [Lauraceae], Origanum vulgare L. [Lamiaceae], Punica granatum L. [Lythraceae], Reynoutria japonica Houtt. [Polygonaceae], and Syzygium aromaticum [L.]. Merr. and L.M.Perry [Myrtaceae]) exerted in vitro growth-inhibitory effects against selected foodborne pathogenic bacteria but not against lactic-acid bacteria. Selective in vitro antibacterial activity was also 
described in the study by Novakova et al. (2013), where the anticlostridial effect of 8-hydroxyquinoline (Microstachys corniculata [Vahl] Griseb. [Euphorbiaceae]) was higher than the activities revealed against different strains of bifidobacteria. In our previous study, we also reported that 8-hydroxyquinoline exerts selective in vitro antiproliferative activity against some intestinal cancer cell lines with a comparably lower effect on normal cells (Kudera et al., 2020). Quinoline alkaloids, such as camptothecin extracted from the bark of Camptotheca acuminata Decne. (Cornaceae), are already being used in chemotherapy for the treatment of colon cancer (Zeng et al., 2013). Anticancer activities of other antibacterially active phytochemicals (e.g., berberine) utilized against infectious diarrhea are currently studied (Lin et al., 2008). Based on these studies, it is evident that plant-derived products have great potential for the development of antibacterial and anticancer preparations for the treatment of infectious diarrhea and associated intestinal cancer diseases. Although many of such products work based on antidiarrheal activity (e.g., antisecretory and astringent effects) (Palombo, 2006), their antimicrobial effect is not an uncommon feature.

The Southeast Asian region is one of the world's major sources of useful plant resources and has long been recognized as a center of plant biodiversity (Duriyaprapan et al., 2005). Situated in the humid tropics with areas of high rainfall, Southeast Asia has one of the largest numbers of vascular plants species globally. For centuries, people living in this region have relied on traditional medicine using available plants for daily healthcare. Cambodia and the Philippines are two geographically distinct Southeast Asian countries, each having numerous plant biodiversity hotspots and a long tradition of herbalism (de Padua et al., 1999). While the former is situated in the mainland, having rich ecosystems, especially around the Mekong River (Chassagne et al., 2016), the latter is a huge archipelago consisting of approximately 7,107 islands, many of which are the center of endemicity and biodiversity (Guzman et al., 2016).

Diarrhea has been a significant issue in both Cambodia and the Philippines (Our World in Data, 2011). Therefore, plant resources in these countries have extensively been utilized medicinally to treat this ailment. The Philippines also has the highest estimated number of cases of colorectal cancer in Southeast Asia and the tenth highest number of deaths in the world (Rawla et al., 2019). In certain provinces of Cambodia, treatment of digestive disorders, such as abdominal pain (chhu poh), diarrhea (reak ach), and dysentery (reak muol), has particularly been based on herbal medicine. Alcohol maceration is a common method of preparation of antidiarrheal medicines, whereas a majority of the preparations are administered orally: drunk, eaten, or chewed (Kham, 2004). Grilling the plant part over a fire and then boiling it into a form of decoction is also common. As an example, Bunong people in Mondulkiri province treat diarrhea using a "step-by-step" process using a sole ingredient from one plant that is substituted by a different species if the condition becomes persistent. In the Philippines, conditions such as diarrhea (pagtatae) and dysentery (pagdidisenyo) have similarly been treated by orally administered herbal preparations that are processed by alcohol maceration, decoction, or infusion or eaten and chewed raw. According to the Philippine traditional medicinal system, the disease is usually conceptualized as a disruption (dys-krasia) of the balance of forces (whether germs or evil spirits), both external and internal to humans. Therefore, it can be assumed that the use of herbal preparations is intended to also defend the immunological mechanisms, helping the body to overcome the disease itself (Tan, 1980). Despite the existence of several reports on the antibacterial and antiproliferative effects of Cambodian and Philippine medicinal plants used for the treatment of diarrhea (Beloy et al., 1976; Chea et al., 2007), there are several species in both regions that have not yet been appropriately studied using modern scientific techniques. In this study, we, therefore, examine the in vitro selective antibacterial and antiproliferative effects of ethanolic extracts from various parts of plant species that have been used in Cambodian and Philippine traditional herbal systems the treatment of gastrointestinal disorders and determine which bioactive properties have not been properly tested in such form and degree before.

\section{MATERIALS AND METHODS}

\section{Plant Materials}

The criteria for selection of promising plant species included their uses for the treatment of diarrhea, dysentery, abdominal pain, and other gastrointestinal complaints in traditional herbal systems of Southeast Asia, particularly Cambodia and the Philippines. Therefore, the appropriate literature on ethnobotany and ethnomedicine of this region was primarily used (Chassagne et al., 2016; de Padua et al., 1999; van Duong, 1993; Kham, 2004; Langenberger et al., 2008; Lemmens and Bunyapraphatsara, 2003; Lim, 2012; Stuart, 2017; Tan, 1980; van Valkenburg and Bunyapraphatsara, 2001). Additionally, several species were identified through meetings with local herbalists in Cambodia (2) and the Philippines (1), assembled by local experts Dr. Nguon and Dr. Bande, respectively. Overall, more than 100 plant species were selected, referring to a limited number of previous studies testing their bioactivity in vitro. A total of 35 samples from different parts (bark, fruit, leaves, or roots, one per plant except three of the species) of 13 Cambodian and 19 Philippine medicinal plant species were collected from various locations in the Republic of the Philippines in April-May 2017 and 2018 and in the Kingdom of Cambodia in March-April 2019 (Table 1). The collected fresh samples were subsequently airdried for several days and sent to the Czechia for further processing and bioactivity testing. Ethnobotany expert Prof. Kokoska and local experts Dr. Bande and Dr. Nguon authenticated the species. Their voucher specimens have been deposited in the herbarium of the Department of Botany and Plant Physiology of the Faculty of Agrobiology, Food and Natural Resources of the Czech University of Life Sciences Prague (Prague, Czechia). The scientific names of the collected species were reviewed using (The Plant List, 2013), and their local names were verified with data from literature and local herbalists (Tan, 1980; van Duong, 1993; de Padua et al., 1999; van Valkenburg and 
TABLE 1 | Ethnobotanical data on Cambodian and Philippine medicinal plants.

\begin{tabular}{|c|c|c|c|c|c|c|}
\hline $\begin{array}{l}\text { Latin name } \\
\text { (family) }\end{array}$ & $\begin{array}{l}\text { GPS coordinates } \\
\text { (country) }\end{array}$ & Local name & $\begin{array}{c}\text { Voucher } \\
\text { specimen }\end{array}$ & Tested part(s) & $\begin{array}{l}\text { Extract yield } \\
(\%)\end{array}$ & Ethnomedicinal use \\
\hline $\begin{array}{l}\text { Aganonerion polymorphum } \\
\text { Spire (Apocynaceae) }\end{array}$ & $\begin{array}{c}12.3966000 \mathrm{~N} \\
107.1934975 \mathrm{E}(\mathrm{C})\end{array}$ & Vor Thneung & 02559KBFRC & Whole plant & 19.7 & Diarrhea (Chassagne et al. (2016)) \\
\hline $\begin{array}{l}\text { Acalypha grandis Benth. } \\
\text { (Euphorbiaceae) }\end{array}$ & $\begin{array}{c}10.7623297 \mathrm{~N} \\
124.8062889 \mathrm{E}(\mathrm{P})\end{array}$ & Unknown & 02537KBFR8 & Leaves & 23.6 & $\begin{array}{l}\text { Diarrhea and dysentery; sapped/crushed } \\
\text { into water/food (van Valkenburg and } \\
\text { Bunyapraphatsara (2001)) }\end{array}$ \\
\hline $\begin{array}{l}\text { Acanthus ebracteatus Vahl } \\
\text { (Acanthaceae) }\end{array}$ & $\begin{array}{c}\text { 10.6888289N, } \\
124.7956483 E(P)\end{array}$ & Diluario & 02505KBFR3 & Whole plant & 17.9 & $\begin{array}{l}\text { Abdominal pain; decoction of 30-60 } \\
\text { gDW (Stuart. (2017)) }\end{array}$ \\
\hline $\begin{array}{l}\text { Ancistrocladus tectorius } \\
\text { (Lour.) Merr. } \\
\text { (Ancistrocladaceae) }\end{array}$ & $\begin{array}{c}13.7333775 \mathrm{~N} \\
107.0151108 \mathrm{E}(\mathrm{C})\end{array}$ & Khan Maa & 02560KBFR4 & Leaves & 16 & $\begin{array}{l}\text { Dysentery; decoction (Lemmens and } \\
\text { Bunyapraphatsara (2003); interviewed } \\
\text { herbalist) }\end{array}$ \\
\hline $\begin{array}{l}\text { Aporosa villosa (Lindl.) Baill. } \\
\text { (Phyllanthaceae) }\end{array}$ & $\begin{array}{c}12.3965292 \mathrm{~N} \\
107.1938597 \mathrm{E}(\mathrm{C})\end{array}$ & Krong & 02561KBFR5 & Leaves & 6.1 & $\begin{array}{l}\text { Diarrhea and abdominal pain; decoction } \\
\text { (Chassagne et al. (2016)) }\end{array}$ \\
\hline $\begin{array}{l}\text { Artocarpus blancoi (Elmer) } \\
\text { Merr. (Moraceae) }\end{array}$ & $\begin{array}{c}10.7435833 \mathrm{~N} \\
124.8020564 \mathrm{E}(\mathrm{P})\end{array}$ & Antipolo & 02538KBFR9 & Fruit & 25.7 & $\begin{array}{l}\text { Diarrhea; cooked (Tan. (1980); Stuart. } \\
(2017))\end{array}$ \\
\hline $\begin{array}{l}\text { Artocarpus camansi Blanco } \\
\text { (Moraceae) }\end{array}$ & $\begin{array}{c}\text { 10.6819242N, } \\
124.8001064 \mathrm{E}(\mathrm{P})\end{array}$ & Kamansi & 02512KBFR1 & Bark & 13.3 & $\begin{array}{l}\text { Diarrhea; cooked (Tan. (1980); Stuart. } \\
(2017))\end{array}$ \\
\hline $\begin{array}{l}\text { Artocarpus elasticus Reinw. ex } \\
\text { Blume (Moraceae) }\end{array}$ & $\begin{array}{c}10.7435939 N \\
124.8019275 E(P)\end{array}$ & Terap & 02539KBFRA & Bark & 11.8 & $\begin{array}{l}\text { Dysentery (Lim, 2012; interviewed } \\
\text { herbalist) }\end{array}$ \\
\hline $\begin{array}{l}\text { Artocarpus odoratissimus } \\
\text { Blanco (Moraceae) }\end{array}$ & $\begin{array}{c}\text { 10.7436072N, } \\
124.8017989 \mathrm{E}(\mathrm{P})\end{array}$ & Marang & 02540KBFR2 & Fruit & 22.9 & $\begin{array}{l}\text { Diarrhea (Lim. (2012); interviewed } \\
\text { herbalist) }\end{array}$ \\
\hline $\begin{array}{l}\text { Bauhinia malabarica Roxb. } \\
\text { (Leguminosae) }\end{array}$ & $\begin{array}{c}12.4428908 \mathrm{~N} \\
107.1592217 \mathrm{E}(\mathrm{C})\end{array}$ & Choeung Koo & 02562KBFR6 & Bark and leaves & 14.7 and 11.2 & $\begin{array}{l}\text { Diarrhea and abdominal pain; alcohol } \\
\text { maceration or decoction (Chassagne } \\
\text { et al. (2016)) }\end{array}$ \\
\hline $\begin{array}{l}\text { Breynia cernua (Poir.) Müll.Arg. } \\
\text { (Phyllantaceae) }\end{array}$ & $\begin{array}{c}\text { 9.8153556N, } \\
124.3597258 \mathrm{E}(\mathrm{P})\end{array}$ & Mutang-Ulang & 02541KBFR3 & Bark & 10.6 & $\begin{array}{l}\text { Dysentery; infusion (van Valkenburg and } \\
\text { Bunyapraphatsara (2001)) }\end{array}$ \\
\hline $\begin{array}{l}\text { Breynia vitis-idaea (Burm.f.) } \\
\text { C.E.C.Fisch. (Phyllanthaceae) }\end{array}$ & $\begin{array}{c}11.5627122 \mathrm{~N} \\
104.9167906 \mathrm{E}(\mathrm{C})\end{array}$ & Phnek Preab & 02563KBFR7 & Wood with bark & 9.9 & Dysentery; infusion (Kham, 2004) \\
\hline $\begin{array}{l}\text { Commelina communis L. } \\
\text { (Commelinaceae) }\end{array}$ & $\begin{array}{c}\text { 10.6159294N, } \\
124.9272431 \mathrm{E}(\mathrm{P})\end{array}$ & Alibangon & 02542KBFR4 & Whole plant & 13.3 & $\begin{array}{l}\text { Diarrhea (van Valkenburg and } \\
\text { Bunyapraphatsara (2001)) }\end{array}$ \\
\hline $\begin{array}{l}\text { Cyathula prostrata (L.) Blume } \\
\text { (Amaranthaceae) }\end{array}$ & $\begin{array}{c}10.7433806 \mathrm{~N} \\
124.8001225 \mathrm{E}(\mathrm{P})\end{array}$ & Dayang & 02543KBFR5 & Whole plant & 12.8 & $\begin{array}{l}\text { Dysentery and cholera; decoction or } \\
\text { infusion (van Valkenburg and } \\
\text { Bunyapraphatsara (2001); Stuart. (2017)) }\end{array}$ \\
\hline $\begin{array}{l}\text { Diplazium esculentum (Retz.) } \\
\text { Sw. (Athyriaceae) }\end{array}$ & $\begin{array}{c}10.7577433 \mathrm{~N} \\
124.7975153 \mathrm{E}(\mathrm{P})\end{array}$ & Paco & 02545KBFR7 & Rhizome & 5.4 & $\begin{array}{l}\text { Diarrhea and dysentery; pulverization and } \\
\text { cold water maceration (Stuart. (2017); } \\
\text { interviewed herbalist) }\end{array}$ \\
\hline $\begin{array}{l}\text { Ehretia microphylla Lam. } \\
\text { (Boraginaceae) }\end{array}$ & $\begin{array}{c}10.7442369 N \\
124.7897825 E(P)\end{array}$ & Tsaang-Gubat & 02489KBFRE & Leaves & 15.3 & $\begin{array}{l}\text { Diarrhea, dysentery, and abdominal pain; } \\
\text { decoction or infusion ( } 8 \text { tbsp of chopped } \\
\text { leaves in } 2 \text { glasses) (de Padua et al. } \\
\text { (1999); Stuart. (2017)) }\end{array}$ \\
\hline $\begin{array}{l}\text { Emilia sonchifolia (L.) DC. ex } \\
\text { DC. (Compositae) }\end{array}$ & $\begin{array}{c}10.7407072 \mathrm{~N} \\
124.8002914 \mathrm{E}(\mathrm{P})\end{array}$ & Tagulinaw & 02520KBFRO & Whole plant & 20.9 & $\begin{array}{l}\text { Diarrhea, dysentery, and enteritis; } \\
\text { decoction (6-15 gDW) (Tan. (1980); } \\
\text { Stuart. (2017)) }\end{array}$ \\
\hline $\begin{array}{l}\text { Helicteres angustifolia L. } \\
\text { (Malvaceae) }\end{array}$ & $\begin{array}{c}12.3963028 \mathrm{~N} \\
107.1938622 \mathrm{E}(\mathrm{C})\end{array}$ & $\begin{array}{l}\text { Sambok } \\
\text { Cheas }\end{array}$ & 02564KBFR8 & Root & 9.2 & $\begin{array}{l}\text { Diarrhea, dysentery, and abdominal pain; } \\
\text { decoction (Chassagne et al. (2016)) }\end{array}$ \\
\hline $\begin{array}{l}\text { Hyptis capitata Jacq. } \\
\text { (Lamiaceae) }\end{array}$ & $\begin{array}{c}10.7590292 \mathrm{~N} \\
124.8020589 \mathrm{E}(\mathrm{P})\end{array}$ & Botonesan & 02546KBFR8 & Whole plant & 10.1 & $\begin{array}{l}\text { Gastrointestinal problems; decoction } \\
\text { (Lemmens and Bunyapraphatsara } \\
(2003))\end{array}$ \\
\hline $\begin{array}{l}\text { Ixora nigricans R.Br. ex Wight } \\
\text { and Arn. (Rubiaceae) }\end{array}$ & $\begin{array}{c}13.7291931 \mathrm{~N} \\
107.0113667 \mathrm{E}(\mathrm{C})\end{array}$ & $\begin{array}{l}\text { Phka Mochul } \\
\text { Pich }\end{array}$ & 02565KBFR9 & Leaves & 10.8 & $\begin{array}{l}\text { Dysentery and abdominal pain (Kham. } \\
(2004))\end{array}$ \\
\hline $\begin{array}{l}\text { Kyllinga brevifolia Rottb. } \\
\text { (Cyperaceae) }\end{array}$ & $\begin{array}{c}11.0610592 \mathrm{~N} \\
124.7009597 \mathrm{E}(\mathrm{P})\end{array}$ & Pugo-Pugo & 02544KBFR6 & Whole plant & 11.4 & $\begin{array}{l}\text { Diarrhea (de Padua et al. (1999); Stuart. } \\
(2017))\end{array}$ \\
\hline $\begin{array}{l}\text { Lagerstroemia } \\
\text { cochinchinensis Pierre ex } \\
\text { Gagnep. (Lythraceae) }\end{array}$ & $\begin{array}{c}13.4692872 \mathrm{~N} \\
105.8909203 \mathrm{E}(\mathrm{C})\end{array}$ & Sralao & 02566KBFRA & Bark & 2.8 & $\begin{array}{l}\text { Diarrhea; decoction (Chassagne et al. } \\
(2016))\end{array}$ \\
\hline $\begin{array}{l}\text { Leea indica (Burm. f.) Merr. } \\
\text { (Vitaceae) }\end{array}$ & $\begin{array}{c}11.5627122 \mathrm{~N} \\
104.9167906 \mathrm{E}(\mathrm{C})\end{array}$ & Kdaing Baay & 02567KBFRB & Root & 8.3 & $\begin{array}{l}\text { Diarrhea, dysentery, digestive and } \\
\text { intestinal complaints; decoction or } \\
\text { infusion (Kham. (2004)) }\end{array}$ \\
\hline $\begin{array}{l}\text { Melastoma dodecandrum } \\
\text { Lour. (Melastomataceae) }\end{array}$ & $\begin{array}{c}12.4089644 \mathrm{~N} \\
107.3133011 \mathrm{E}(\mathrm{C})\end{array}$ & Unknown & 02568KBFRC & $\begin{array}{l}\text { Bark and leaves } \\
\text { with flower buds }\end{array}$ & 12.7 and 9.9 & Diarrhea (van Duong. (1993)) \\
\hline $\begin{array}{l}\text { Melastoma saigonense } \\
\text { (Kuntze) Merr. } \\
\text { (Melastomataceae) }\end{array}$ & $\begin{array}{c}11.5627122 \mathrm{~N} \\
104.9167906 \mathrm{E}(\mathrm{C})\end{array}$ & Baay Nhenh & 02569KBFRD & $\begin{array}{l}\text { Wooden stem } \\
\text { and leaves with } \\
\text { flower buds }\end{array}$ & 7.3 and 17.3 & Diarrhea (Chassagne et al. (2016)) \\
\hline
\end{tabular}


TABLE 1 | (Continued) Ethnobotanical data on Cambodian and Philippine medicinal plants.

\begin{tabular}{|c|c|c|c|c|c|c|}
\hline $\begin{array}{l}\text { Latin name } \\
\text { (family) }\end{array}$ & $\begin{array}{l}\text { GPS coordinates } \\
\text { (country) }\end{array}$ & Local name & $\begin{array}{l}\text { Voucher } \\
\text { specimen }\end{array}$ & Tested part(s) & $\begin{array}{l}\text { Extract yield } \\
(\%)\end{array}$ & Ethnomedicinal use \\
\hline $\begin{array}{l}\text { Parkia javanica (Lam.) Merr. } \\
\text { (Leguminosae) }\end{array}$ & $\begin{array}{c}10.7448892 \mathrm{~N} \\
124.8059375 \mathrm{E}(\mathrm{P})\end{array}$ & Kupang & 02547KBFR9 & Bark & 25.7 & $\begin{array}{l}\text { Diarrhea and dysentery; decoction (Tan. } \\
\text { (1980); Stuart. (2017)) }\end{array}$ \\
\hline $\begin{array}{l}\text { Pentacme siamensis (Miq.) } \\
\text { Kurz (Dipterocarpaceae) }\end{array}$ & $\begin{array}{c}13.4474300 \mathrm{~N} \\
105.8756317 \mathrm{E}(\mathrm{C})\end{array}$ & Raing Phnom & 02571KBFR6 & Bark & 5.8 & Diarrhea (Chassagne et al. (2016) \\
\hline $\begin{array}{l}\text { Picrasma javanica Blume } \\
\text { (Simaroubaceae) }\end{array}$ & $\begin{array}{c}10.7438825 \mathrm{~N} \\
124.8039956 \mathrm{E}(\mathrm{P})\end{array}$ & Manunggal & 02548KBFRA & Bark & 6.3 & $\begin{array}{l}\text { Digestive and abdominal pain; decoction } \\
\text { (Langenberger et al. (2008)) }\end{array}$ \\
\hline $\begin{array}{l}\text { Pseudelephantopus spicatus } \\
\text { (Juss. ex Aubl.) Rohr } \\
\text { (Compositae) }\end{array}$ & $\begin{array}{c}\text { 9.8110686N, } \\
124.3551231 \mathrm{E}(\mathrm{P})\end{array}$ & Kokunbanog & 02553KBFR6 & Whole plant & 12.5 & $\begin{array}{l}\text { Diarrhea; decoction (Langenberger et al. } \\
(2008) \text { ) }\end{array}$ \\
\hline $\begin{array}{l}\text { Rourea minor (Gaertn.) Alston } \\
\text { (Connaraceae) }\end{array}$ & $\begin{array}{c}12.3965372 \mathrm{~N} \\
107.1933392 \mathrm{E}(\mathrm{C})\end{array}$ & Unknown & 02570KBFR5 & Leaves & 11.4 & Diarrhea (Chassagne et al. (2016)) \\
\hline $\begin{array}{l}\text { Tabernaemontana } \\
\text { pandacaqui Lam. } \\
\text { (Apocynaceae) }\end{array}$ & $\begin{array}{c}\text { 14.1667808N, } \\
121.2143336 \mathrm{E}(\mathrm{P})\end{array}$ & $\begin{array}{l}\text { Pandakaking- } \\
\text { Puti }\end{array}$ & 02503KBFR1 & Bark & 10.1 & Gastroenteritis (Tan. (1980)) \\
\hline $\begin{array}{l}\text { Triumfetta bartramia L. } \\
\text { (Malvaceae) }\end{array}$ & $\begin{array}{c}10.7467864 \mathrm{~N} \\
124.8152500 \mathrm{E}(\mathrm{P})\end{array}$ & Kulutkulutan & 02554KBFR7 & Root & 14.9 & $\begin{array}{l}\text { Diarrhea and intestinal ulcers (van } \\
\text { Valkenburg and Bunyapraphatsara } \\
\text { (2001); Stuart. (2017)) }\end{array}$ \\
\hline
\end{tabular}

C, Cambodia; P, Philippines.

Bunyapraphatsara, 2001; Lemmens and Bunyapraphatsara, 2003; Kham, 2004; Langenberger et al., 2008; Lim, 2012; Chassagne et al., 2016; Stuart, 2017). For all assayed species, the scientific names, families, local names, voucher specimen codes, GPS coordinates, collected parts (plant samples), and their uses in folk medicine are presented in Table 1.

\section{Preparation of Plant Extracts}

Although the most common procedures of processing antidiarrheal plants in Cambodia and the Philippines are decoction and infusion (Table 1), ethanol was selected for the extraction of plant samples since it is an efficient solvent for herbal drugs with a well-established tradition in herbal medicine (Kelber et al., 2016). With the aim of preventing possible loss or changes of active constituents due to storage of plant samples, the extraction was performed immediately after their arrival in the Czechia. Each dried sample was homogenized into powder using Grindomix mill (Retsch, Haan, Germany), and $15 \mathrm{~g}$ of dry matter was extracted in $450 \mathrm{ml}$ 80\% ethanol (Penta, Prague, Czechia) for $24 \mathrm{~h}$ at room temperature using a laboratory shaker (GFL3005, GFL, Burgwedel, Germany). Therefore, the drug extract ratio was 1:30. Extracts were subsequently filtered and concentrated using a rotary vacuum evaporator (R-200, Buchi Labortechnik, Flawil, Switzerland) in vacuo at $40^{\circ} \mathrm{C}$. According to the recommendations of $\mathrm{Cos}$ et al. (2006), the dried residue was finally diluted in $100 \%$ dimethylsulfoxide (DMSO) (Penta, Prague, Czechia) to obtain stock solutions with a final concentration of $51.2 \mathrm{mg} / \mathrm{ml}$ and stored at $-20^{\circ} \mathrm{C}$ until their use. Some of the extracts were not completely soluble in other solvents, such as distilled water. Yields (\%) of the dried residues are shown in Table 1.

\section{Bacterial Strains and Media}

The intestinal bacterial type strains were obtained from the American Type Culture Collection (ATCC, Rockville, MD, United States), Czech Collection of Microorganisms (CCM,
Brno, Czechia), German Collection of Microorganisms and Cell Cultures (DSMZ, Braunschweig, Germany), and National Collection of Type Cultures (NCTC, London, United Kingdom).

In accordance with the diversity of diarrheagenic grampositive and gram-negative bacteria responsible for globally distributed foodborne, waterborne, and nosocomial infections (Diniz-Santos et al., 2006; Rajkovic et al., 2020), the following 12 strains were used in this study: B. cereus (ATCC 14579), C. difficile (DSMZ 12056), C. perfringens (DSMZ 11778), E. faecalis (ATCC 29212), E. coli (ATCC 25922), E. coli 0175:H7 (NCTC 12900), L. monocytogenes (ATCC 7644), Shigella flexneri (ATCC 12022), Salmonella enterica ssp. enterica serovar Enteritidis (ATCC 13076), S. enterica ssp. enterica serovar Typhimurium (ATCC 14028), V. parahaemolyticus (ATCC 17802), and Y. enterocolitica (ATCC 9610). The above-mentioned strains were considered as obligate or facultative pathogens. The following six bacterial strains, which belong to the dominant bacterial phyla in the human gut and exhibit probiotic functions (Behnsen et al., 2013), were used in this study: Bifidobacterium adolescentis (DSMZ 20087), Bifidobacterium animalis spp. lactis (DSMZ 10140), Bifidobacterium breve (ATCC 15700), Lactobacillus casei (DSMZ 20011), Lactobacillus reuteri (CCM 3625), and Lactobacillus rhamnosus (CCM 7091). All these strains were considered beneficial gut bacteria.

As the maintenance and growth medium, Mueller-Hinton Broth (Oxoid, Basingstoke, United Kingdom) was used for the majority of bacteria that grow aerobically (E. faecalis supp. $1 \%$ glucose, $V$. parahaemolyticus supp. $3 \% \mathrm{NaCl}$ ). Y. enterocolitica was stored and cultured in Brain Heart Infusion Broth (Oxoid, Basingstoke, United Kingdom). Bifidobacteria and lactobacilli were maintained and cultured in Wilkins-Chalgren Broth (Oxoid, Basingstoke, United Kingdom) supplemented with $5 \mathrm{~g} /$ $\mathrm{L}$ soya peptone and $0.5 \mathrm{~g} / \mathrm{L}$ cysteine. Although the same growth medium was used for clostridia, they were stored in cooked meat medium (both from Oxoid, Basingstoke, United Kingdom) at room temperature. The standard safety guidelines for handling 
microorganisms were followed. Therefore, all items, such as culture tubes, syringes, and gloves, were discarded in the biohazard autoclave bag after every use.

\section{Cell Cultures}

One representative of normal intestinal cell line (FHs 74 Int [ATCC CCL 241]) and two of cancer intestinal cell lines (Caco-2 [ATCC HTB 37]) and HT-29 [ATCC HTB 38]) were purchased from ATCC (Rockville, MD, United States). Normal cells were cultured in Hybri-Care medium supplemented with $10 \%$ fetal bovine serum, $1 \%$ sodium bicarbonate, $1 \%$ nonessential amino acids, $30 \mathrm{ng} / \mathrm{ml}$ of epidermal growth factor, and $1 \%$ penicillinstreptomycin solution (10,000 units $/ \mathrm{ml}$ and $100 \mathrm{mg} / \mathrm{ml}$, respectively). The cancer cells were cultured in Eagle's Minimum Essential Medium (EMEM) supplemented with 1\% sodium pyruvate, $10 \%$ fetal bovine serum, $1 \%$ sodium bicarbonate, $1 \%$ nonessential amino acids, and $1 \%$ penicillinstreptomycin solution $(10,000$ units $/ \mathrm{ml}$ and $100 \mathrm{mg} / \mathrm{ml}$, respectively) (all purchased from Biowest, Nuaille, France). The cultures were incubated at $37^{\circ} \mathrm{C}$ and $5 \% \mathrm{CO}_{2}$. The culture medium was replaced every $2-3$ days, and cells were passaged every 7 days.

\section{Antibacterial Assay}

Initially, all 35 extracts (Table 1) were evaluated for their antibacterial activities against the pathogenic strains. Those showing any inhibitory action were subsequently tested against the probiotic strains. The growth-inhibitory activities against aerobic and anaerobic bacteria were evaluated using the broth microdilution method using 96-well microtiter plates, following the protocols of (Clinical and Laboratory Standards Institute, 2021) and Hecht (1999), respectively. For the effective assessment of the anti-infective potential of natural products, slight modifications were implemented as described by Cos et al. (2006).

Prior to testing, the strains that grow aerobically were subcultured in the appropriate media at $37^{\circ} \mathrm{C}$ (Y. enterocolitica at $30^{\circ} \mathrm{C}$ ) for $24 \mathrm{~h}$. Bifidobacteria, clostridia, and lactobacilli were cultured at $37^{\circ} \mathrm{C}$ for $48 \mathrm{~h}$ using Whitley A35 Anaerobic Workstation (Don Whitley Scientific, Bingley, United Kingdom). The anaerobic conditions were created by supplying a standard anaerobic gas mixture of $10 \% \mathrm{H}_{2}, 10 \% \mathrm{CO}_{2}$, and $80 \% \mathrm{~N}_{2}$ (Linde Gas, Prague, Czechia).

The extracts were diluted twofold in appropriate growth media (initial concentration of $512 \mu \mathrm{g} / \mathrm{ml}$ ) using the Freedom EVO 100 automated pipetting platform (Tecan, Männedorf, Switzerland) and multichannel pipette (Eppendorf, Hamburg, Germany) in case of aerobic and anaerobic bacteria, respectively. After the optimalization of bacterial cultures to inoculum density of 1.5 $\times 10^{8} \mathrm{CFU} / \mathrm{ml}$ by $0.5 \mathrm{McF}$ arland standard using Densi-LaMeter II (Lachema, Brno, Czechia), the cultures were inoculated in 96-well plates $(5 \mu \mathrm{l} /$ well). Bacterial cultures in microplates were incubated by employing the same protocols as used for their cultivation prior to the test. The optical density of the cultures was measured at $405 \mathrm{~nm}\left(\mathrm{OD}_{450} \mathrm{~nm}\right)$ using a Cytation 3 Imaging Reader (BioTek, Winooski, VT, United States) before and after the growth period.
The lowest concentration $(\mu \mathrm{g} / \mathrm{ml})$ of the extracts that inhibited the bacterial growth by $\geq 80 \%$ was defined as the minimum inhibitory concentration (MIC). Ciprofloxacin (Sigma-Aldrich, Prague, Czechia), an antibiotic commonly recommended for the treatment of infectious diarrhea (Casburn-Jones, 2004), was dissolved in distilled water and used as a positive control drug. All tests were performed as three independent experiments, each conducted in triplicate. The mode and median were used for the final MIC value calculation when the triplicate endpoints were within the two- and three-dilution ranges, respectively. The antibacterial activities were classified as strong (MICs $\leq 64 \mu \mathrm{g}$ / $\mathrm{ml})$, moderate $(\mathrm{MICs}=128-256 \mu \mathrm{g} / \mathrm{ml})$, and weak $(\mathrm{MIC}=$ $512 \mu \mathrm{g} / \mathrm{ml}$ ) (Kokoska et al., 2019). As a result of experiments performed without dissolved extracts and ciprofloxacin (SigmaAldrich, Prague, Czechia), their respective solvents, namely, DMSO (Sigma-Aldrich, Prague, Czechia) and distilled water, did not inhibit bacterial growth of any strain at the tested concentrations $(\leq 1 \%)$.

\section{Cytotoxicity Assay}

The antiproliferative activities of the extracts that showed some inhibitory action against the tested bacteria were further assessed using the modified thiazolyl blue tetrazolium bromide (MTT) cytotoxicity assay developed by Mosmann (1983). Cancer $(2.5 \times$ $\left.10^{3}\right)$ and normal intestinal $\left(2.5 \times 10^{5}\right)$ cells were seeded in a 96well microtiter plate for $24 \mathrm{~h}$. Cells were incubated with twofold serially diluted plant extracts $(0.25-512 \mu \mathrm{g} / \mathrm{ml})$ for $72 \mathrm{~h}$. Next, the cells were incubated with MTT reagent $(1 \mathrm{mg} / \mathrm{ml}$ ) (SigmaAldrich, Prague, Czechia) in EMEM or Hybri-Care medium for an additional $2 \mathrm{~h}$ at $37^{\circ} \mathrm{C}$ and $5 \% \mathrm{CO}_{2}$. The medium with MTT was removed, and the intracellular formazan product was dissolved in $100 \mu \mathrm{l}$ DMSO. The absorbance was measured at $555 \mathrm{~nm}$ using a Tecan Infinite M200 spectrometer (Tecan, Männedorf, Switzerland), and the percentage of viability was calculated when compared to an untreated control.

The antiproliferative activity of the tested plant extracts was represented as half-maximal inhibitory concentration $\left(\mathrm{IC}_{50} ; \mu \mathrm{g} /\right.$ $\mathrm{ml})$. The colon cancer chemotherapeutic drug 5-fluorouracil (Sigma-Aldrich, Prague, Czechia) was used as a positive control (Fuente et al., 2020). Three independent experiments (two replicates each) were performed for every test. Data are presented as mean \pm standard deviation. The antiproliferative activity was evaluated as follows: cytotoxic $\left(\mathrm{IC}_{50}\right.$ values $\leq 100 \mu \mathrm{g} /$ $\mathrm{ml})$, moderately cytotoxic $\left(\mathrm{IC}_{50}\right.$ values $\left.=100-400 \mu \mathrm{g} / \mathrm{ml}\right)$, and weakly cytotoxic $\left(\mathrm{IC}_{50}\right.$ values $=401-512 \mu \mathrm{g} / \mathrm{ml}$ ) (Srisawat et al., 2013). The solvents did not affect the viability of normal and cancer intestinal cell lines at the tested concentration $(\leq 1 \%)$.

\section{Calculations}

For comparison of microbiological and toxicological data, $80 \%$ bacterial growth inhibition $\left(\mathrm{IC}_{80}\right)$ was calculated as equivalent to the MIC endpoint (Houdkova et al., 2018). Subsequently, $\bar{x}$-MIC, $\bar{x}$ - $\mathrm{IC}_{50}$, and $\bar{x}$ - $\mathrm{IC}_{80}$ values ( \pm standard deviations) were calculated to quantify the inhibitory activity of the tested plant extracts against pathogenic/beneficial bacteria and intestinal cancer/normal cells. Subsequently, the selectivity index (SI) was calculated between normal intestinal cells and pathogenic 
TABLE 2 | In vitro selective inhibitory activities of ethanolic extracts of Cambodian and Philippine plants against intestinal bacteria and cells.

\begin{tabular}{|c|c|c|c|c|c|c|c|c|c|c|c|c|c|c|c|c|c|c|c|c|}
\hline & \multicolumn{18}{|c|}{ Plant species with their parts and positive antibiotic and anticancer control } \\
\hline \multicolumn{3}{|c|}{ Cultures tested } & \multirow{2}{*}{$\begin{array}{c}\boldsymbol{A P}(w) \\
{ }^{a}\end{array}$} & \multirow{2}{*}{$\begin{array}{c}\boldsymbol{A G}(\boldsymbol{I}) \\
512\end{array}$} & \multirow{2}{*}{$\begin{array}{c}\boldsymbol{A T}(\boldsymbol{I}) \\
64\end{array}$} & \multirow{2}{*}{$\begin{array}{c}\boldsymbol{A B}(\boldsymbol{f}) \\
64\end{array}$} & \multirow{2}{*}{$\begin{array}{c}\boldsymbol{A C}(\boldsymbol{b}) \\
256\end{array}$} & \multirow{2}{*}{$\begin{array}{c}\boldsymbol{B M}(\boldsymbol{b}) \\
512\end{array}$} & \multirow{2}{*}{$\begin{array}{c}B V(w b) \\
-\end{array}$} & \multirow{2}{*}{$\begin{array}{c}D E(r) \\
-\end{array}$} & \multirow{2}{*}{$\begin{array}{c}E M(I) \\
512\end{array}$} & \multirow{2}{*}{$\begin{array}{c}I N(I) \\
-\end{array}$} & \multirow{2}{*}{$L C(b)$} & \multirow{2}{*}{$M D(b)$} & \multirow{2}{*}{$\begin{array}{c}M D(f f) \\
-\end{array}$} & \multirow{2}{*}{$\begin{array}{c}\boldsymbol{M S}(\boldsymbol{f f}) \\
512\end{array}$} & \multirow{2}{*}{$\begin{array}{c}P J(b) \\
-\end{array}$} & \multirow{2}{*}{$\begin{array}{c}\boldsymbol{P S ( b )} \\
256\end{array}$} & \multirow{2}{*}{$\begin{array}{c}\text { CIP } \\
1\end{array}$} & 5-FU \\
\hline Bacterial & train/ & $\mathrm{BC}$ & & & & & & & & & & & & & & & & & & nd \\
\hline MIC & & $C D$ & 512 & 512 & 512 & 32 & 128 & - & & - & 512 & 512 & - & - & 512 & 512 & - & - & 16 & nd \\
\hline$(\mu \mathrm{g} / \mathrm{mll})$ & & $\mathrm{CP}$ & - & 512 & 512 & 32 & 256 & - & - & - & - & - & - & - & - & - & - & - & 1 & nd \\
\hline & & $\mathrm{EF}$ & - & - & & 128 & & & & & - & & & - & - & - & - & & 2 & nd \\
\hline & & $\mathrm{EC}$ & 512 & - & - & - & - & 256 & 256 & 512 & - & - & - & 256 & - & - & 256 & 256 & 0.062 & nd \\
\hline & & ECS & - & - & - & - & - & - & - & - & - & - & - & - & - & - & - & - & 0.016 & nd \\
\hline & & LM & - & - & 128 & 256 & - & - & - & - & - & - & - & - & - & 512 & - & 512 & 4 & nd \\
\hline & & SF & - & - & - & - & - & - & - & - & - & - & - & - & - & - & - & - & 0.016 & nd \\
\hline & & SE & - & - & - & - & - & - & - & - & - & - & - & - & - & & - & 256 & 0.031 & nd \\
\hline & & ST & - & - & & & & & 256 & - & - & & & - & 512 & - & - & - & 0.031 & nd \\
\hline & & VP & - & 256 & & & & 512 & & & 512 & - & 512 & 512 & 512 & 512 & - & - & 0.062 & nd \\
\hline & & YE & - & - & - & & & - & & - & - & - & - & - & - & - & - & - & 0.125 & nd \\
\hline & & $x-P B \pm$ & $938.7 \pm$ & $832 \pm$ & $784 \pm$ & $640 \pm$ & $821.3 \pm$ & $874.7 \pm$ & $896 \pm$ & $981.3 \pm$ & $896 \pm$ & $981.3 \pm$ & $981.3142 \pm$ & $917.3 \pm$ & $896 \pm$ & 853.3 & $960 \pm$ & $789.3 \pm$ & $2 \pm 6$ & nd \\
\hline & & SD & 191 & 279 & 390 & 458 & 352 & 266 & 286 & 142 & 222 & 142 & & 244 & 222 & \pm 241 & 212 & 338 & & \\
\hline & & BA & 64 & 512 & 256 & 16 & . & - & - & - & 512 & 512 & - & - & 256 & 512 & - & - & 8 & nd \\
\hline & & BB & - & 64 & 64 & 16 & 512 & - & - & - & 128 & 128 & - & - & - & 256 & 128 & - & 64 & nd \\
\hline & & BLC & - & - & 256 & 16 & & & & & 256 & 512 & - & - & - & 512 & - & - & 32 & nd \\
\hline & & LC & 512 & 256 & 128 & 16 & 256 & - & - & - & 128 & 128 & - & - & - & 512 & 512 & 512 & 32 & nd \\
\hline & & $L R$ & - & - & 256 & 16 & - & - & - & - & - & - & - & - & - & - & - & - & 32 & nd \\
\hline & & LRM & - & - & 128 & 16 & 512 & - & - & - & 512 & - & - & & & & & - & 4 & nd \\
\hline & & $\begin{array}{l}x-B B \pm \\
S D\end{array}$ & $\begin{array}{l}778.7 \pm \\
370\end{array}$ & $\begin{array}{l}650.7 \pm \\
395\end{array}$ & $\begin{array}{l}181.3 \pm \\
78\end{array}$ & $16 \pm 0$ & $\begin{array}{l}725.3 \pm \\
311\end{array}$ & $1,024 \pm 0$ & $1,024 \pm 0$ & $1,024 \pm 0$ & $\begin{array}{l}426.7 \pm \\
311\end{array}$ & $\begin{array}{l}554.7 \pm \\
367\end{array}$ & $1,024 \pm 0$ & $1,024 \pm 0$ & $\begin{array}{l}896 \pm \\
286\end{array}$ & $\begin{array}{c}640 \pm \\
286\end{array}$ & $\begin{array}{l}789.3 \pm \\
350\end{array}$ & $\begin{array}{l}938.7 \pm \\
191\end{array}$ & $29 \pm 20$ & nd \\
\hline $\begin{array}{l}\text { Cell line } \\
(\log / \mathrm{l})\end{array}$ & $\mathrm{IC}_{50 \pm}$ & HT -29 & $\begin{array}{l}130.52 \pm \\
2.57\end{array}$ & $\begin{array}{l}96.53 \pm \\
12.41\end{array}$ & $\begin{array}{l}82.19 \pm \\
17.22\end{array}$ & $\begin{array}{l}53.70 \pm \\
16.02\end{array}$ & $\begin{array}{l}84.77 \pm \\
4.20\end{array}$ & $\begin{array}{l}35.195 \pm \\
5.32\end{array}$ & $\begin{array}{l}81.79 \pm \\
2079\end{array}$ & - & $\begin{array}{l}130.89 \pm \\
13.99\end{array}$ & $\begin{array}{l}125.55 \pm \\
13.92\end{array}$ & $\begin{array}{l}37.89 \pm \\
268\end{array}$ & $\begin{array}{l}248.56 \pm \\
23.13\end{array}$ & $\begin{array}{l}210.85 \pm \\
16.83\end{array}$ & $\begin{array}{l}49.75 \pm \\
3.53\end{array}$ & $\begin{array}{l}155.87 \pm \\
41.79\end{array}$ & $51.98 \pm 19.79$ & $\begin{array}{l}88.81 \pm \\
13.44\end{array}$ & $\begin{array}{r}6.35 \\
+2.07\end{array}$ \\
\hline & & Caco- & $148.96 \pm$ & $78.42 \pm$ & $33.82 \pm$ & $79.41 \pm$ & $48.40 \pm$ & 0.02 & 2.19 & . & $52.49 \pm$ & $135.60 \pm$ & $\begin{array}{l}2.000 \\
122.86 \pm\end{array}$ & $193.73 \pm$ & $77.57 \pm$ & $87.40 \pm$ & $121.26 \pm$ & - & $90.87 \pm$ & 181.79 \\
\hline & & 2 & 17.14 & 23.18 & 10.57 & 6.90 & 0.93 & & & & 8.81 & 3.11 & 13.16 & 1.61 & 10.22 & 19.18 & 15.34 & & 17.98 & \pm 151.51 \\
\hline & & $x-\mathrm{CC}_{ \pm}$ & $139.7 \pm$ & $87.5 \pm 9$ & $58 \pm$ & $66.5 \pm$ & $66.5 \pm$ & $529.6 \pm$ & $552.9 \pm$ & - & $91.7 \pm$ & $130.6 \pm 5$ & $80.4 \pm$ & $221.1 \pm$ & $144.2 \pm$ & $68.575 \pm$ & $138.6 \pm$ & $538 \pm 486$ & $89.84 \pm$ & 94 \\
\hline & & SD & 9.2 & & 24.2 & 12.8 & 18 & 494 & 471 & & 39.2 & & & 27.4 & & & & & & \pm 88 \\
\hline & & $\begin{array}{l}\text { FHs } \\
74 \operatorname{lnt}\end{array}$ & $\begin{array}{l}297.39 \pm \\
22.54\end{array}$ & $\begin{array}{l}118.76 \pm \\
36.04\end{array}$ & $\begin{array}{l}45.50 \pm \\
7.29\end{array}$ & $\begin{array}{l}273.32 \pm \\
7.50\end{array}$ & $\begin{array}{l}68.23 \pm \\
12.39\end{array}$ & $\begin{array}{l}158.36 \pm \\
23.75\end{array}$ & $\begin{array}{l}68.75 \pm \\
8.89\end{array}$ & & $\begin{array}{l}303.41 \pm \\
18.00\end{array}$ & $\begin{array}{l}243.50 \pm \\
21.92\end{array}$ & $\begin{array}{l}282.05 \pm \\
0.57\end{array}$ & - & $\begin{array}{l}368.07 \pm \\
30.00\end{array}$ & $\begin{array}{l}195.19 \pm \\
8.94\end{array}$ & $\begin{array}{l}342.62 \pm \\
3.54\end{array}$ & & $\begin{array}{l}58.90 \pm \\
4.27\end{array}$ & $\begin{array}{r}492.43 \\
\pm 22.92\end{array}$ \\
\hline & $1 \mathrm{I}_{80} \pm$ & HT-29 & $130.50 \pm$ & - & $498.17 \pm$ & - & $356.20 \pm$ & - & - & - & - & - & - & $351.26 \pm$ & $378.50 \pm$ & $143.70 \pm$ & - & - & $181.53 \pm$ & 367.26 \\
\hline & SD & & 12.06 & & 16.74 & & 19.04 & & & & & & & 43.24 & 34.93 & 16.74 & & & 15.05 & \pm 0.57 \\
\hline & & $\begin{array}{l}\text { Caco- } \\
2\end{array}$ & - & - & & - & - & - & - & - & - & - & - & - & - & - & - & - & 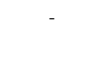 & \\
\hline & & $\begin{array}{l}x-C C \pm \\
S D\end{array}$ & $\begin{array}{l}577.25 \pm \\
446.75\end{array}$ & - & $\begin{array}{l}761.1 \pm \\
263\end{array}$ & - & $\begin{array}{l}690.1 \pm \\
333.9\end{array}$ & - & - & - & - & - & - & $\begin{array}{l}687.63 \pm \\
336.37\end{array}$ & $\begin{array}{l}701.25 \pm \\
322.75\end{array}$ & $\begin{array}{l}583.85 \pm \\
440.15\end{array}$ & - & - & $\begin{array}{l}602.77 \pm \\
421.23\end{array}$ & $\begin{array}{l}695.63 \pm \\
328.37\end{array}$ \\
\hline & & $\begin{array}{l}\text { FHs } \\
74 \operatorname{lnt}\end{array}$ & - & - & - & - & $\begin{array}{l}264.64 \pm \\
6.82\end{array}$ & - & - & - & - & - & - & - & - & - & - & - & $\begin{array}{l}83.37 \pm \\
8.60\end{array}$ & - \\
\hline sI & & (a) & 0.04 & 0.09 & 0.12 & 0.2 & -0.49 & 0.07 & 0.06 & 0.02 & 0.06 & 0.02 & 0.02 & 0.05 & 0.06 & 0.08 & 0.03 & 0.11 & 1.62 & nd \\
\hline & & (b) & -0.1 & -0.1 & -0.6 & -1.6 & -0.1 & 0.1 & 0.1 & 0.02 & -0.3 & -0.2 & 0.02 & 0.05 & 0 & -0.1 & -0.04 & 0.1 & 1.2 & nd \\
\hline & & (c) & 0.3 & 0.1 & -0.1 & 0.6 & 0.01 & -0.5 & -0.9 & 0 & 0.5 & 0.3 & 0.5 & 0.7 & 0.4 & 0.5 & 0.4 & 0.3 & -0.2 & 0.4 \\
\hline & & (d) & 0.13 & -0.2 & -0.62 & -1.81 & 0.02 & 0 & 0 & 0 & -0.38 & -0.27 & 0 & 0.17 & 0.11 & 0.04 & -0.11 & -0.04 & -1.32 & nd \\
\hline
\end{tabular}

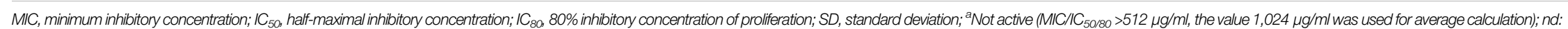
no data. AP(w), Aganonerion polymorphum Spire (whole plant); $A G($ (), Acalypha grandis Benth. (leaves); AT(1), Ancistrocladus tectorius (Lour.) Merr. (leaves); $A B(t)$, Artocarpus blancoi (Elmer) Merr. (fruit); AC(b), Artocarpus camansi Blanco (bark); BM(b)), Bauhinia malabarica Roxb. (bark); BV(wb), Breynia vitis-idaea (Burm.f.) C.E.C.Fisch. (wood with bark); DE(r), Diplazium esculentum (Retz.) S roots); EM(), Ehretia microphylla Lam. (leaves); IN(), Ixora nigricans R.Br. ex Wight and Am. (leaves); LC(b)), Lagerstroemia cochinchinensis Pierre ex Gagnep. (bark); MD(b), Melastoma dodecandrum Lour. (bark); MD(t), Melastoma dodecandrum Lour. (leaves with flower buds); MS(t), Melastoma saigonense (Kuntze) Merr. (leaves with flower buds); PJ(b)), Picrasma javanica Blume (bark); PS(b), Pentacme siamensis (Miqq.) Kurz; ClP, ciprofloxacin; 5-FU, 5-fluorouracil. BC, Bacillus cereus; CD, Clostridlium difficile; CP, Clostridium perfringens; EF, Enterococcus faecalis; EC, Escherichia coli; ECS, E. coli 0, 175:H7; LM, Listeria monocytogenes; SF, Shigella flexneri; SE, Salmonella Enteritidis; ST, Salmonella Typhimurium; VP, Vibrio parahaemolyticus; YE, Yersinia enterocolitica; BA, Bifidobacterium adolescentis; BB, Bifidobacterium breve; BLC, Bifidobacterium animalis Spp. lactis, LC, Lactobacillus casei; LR, Lactobacillus reuteri; LRM, Lactobacillus inamnosus; X-PB, mean MIC for pathogenic bacteria; $X$-BB, mean MIC for beneficial bacteria; $x$-CC, mean IC $50 / 80$ for intestinal cancer cells; $F H$ S 74 Int (intestinal normal cells); SI (selectivity index): (a) normal cells/diarheagenic bacteria, (b) beneficial bacteria/diarheagenic bacteria, (c) normal cells/cancer cells, and (d) beneficial bacteria/cancer cells. 
strains (SIa), beneficial and pathogenic strains (SIb), normal and cancer intestinal cells (SIc), and beneficial strains and cancer intestinal cells (SId) using the following formulas where $\mathrm{X} 1=\mathrm{IC}_{80}$ against normal intestinal cells; $\mathrm{X} 2=\bar{x}$-MIC against beneficial strains; $\mathrm{X} 3=\mathrm{IC}_{50}$ against normal intestinal cells; $\mathrm{Y} 1=\bar{x}$-MIC against pathogenic strains; $\mathrm{Y} 2=\bar{x}$ - $\mathrm{IC}_{50}$ against cancer intestinal cells; and $\mathrm{Y} 3=\mathrm{IC}_{80}$ against cancer intestinal cells:

$$
\begin{aligned}
& \text { SIa }=\log (\mathrm{X} 1 / \mathrm{Y} 1), \\
& \text { SIb }=\log (\mathrm{X} 2 / \mathrm{Y} 1), \\
& \text { SIc }=\log (\mathrm{X} 3 / \mathrm{Y} 2), \\
& \text { SId }=\log (\mathrm{X} 2 / \mathrm{Y} 3) .
\end{aligned}
$$

The SI values $>0$ and $<0$ indicate selective toxicity against pathogenic strains/cancer cell lines and beneficial strains/normal cell lines, respectively.

\section{RESULTS}

\section{Antibacterial Activity Diarrheagenic Bacterial Pathogens}

Considering the antibacterial activity against the pathogens, 16 of 35 tested extracts revealed a growth-inhibitory effect on at least one of these bacterial strains. While B. cereus, C. difficile, E. coli, and $V$. parahaemolyticus were the most susceptible bacteria inhibited by the highest number of extracts, none of the extracts exerted activity against E. coli $\mathrm{O} 157: \mathrm{H} 7$ and $S$. flexneri. The MICs $(32-512 \mu \mathrm{g} / \mathrm{ml})$ of all 16 plant extracts for the diarrheagenic bacterial pathogens are presented in Table 2.

There were four extracts showing promising antibacterial actions against multiple pathogenic bacteria, especially the gram-positive strains. Namely, the fruit extract of Artocarpus blancoi (Elmer) Merr. (Moraceae) inhibited B. cereus and both clostridia at MICs 64 and $32 \mu \mathrm{g} / \mathrm{ml}$, respectively. This plant was also moderately active against $E$. faecalis $(\mathrm{MIC}=128 \mu \mathrm{g} / \mathrm{ml})$ and L. monocytogenes $(\mathrm{MIC}=256 \mu \mathrm{g} / \mathrm{ml})$. Similarly, the leaf extract of Ancistrocladus tectorius (Lour.) Merr. (Ancistrocladaceae) revealed a strong inhibitory effect on $B$. cereus $(\mathrm{MIC}=64 \mu \mathrm{g}$ / $\mathrm{ml}$ ) and moderate activity against $L$. monocytogenes ( $\mathrm{MIC}=$ $128 \mu \mathrm{g} / \mathrm{ml}$ ). However, it produced only weak inhibitory action against both clostridia (MICs $=512 \mu \mathrm{g} / \mathrm{ml})$. Next, bark extract of Artocarpus camansi Blanco (Moraceae) inhibited B. cereus and both clostridia at MICs ranging from 128 to $256 \mu \mathrm{g} / \mathrm{ml}$. Although the antibacterial activities of bark extract of Pentacme siamensis (Miq.) Kurz (Dipterocarpaceae) were rather moderate, it exerted inhibitory action against several gram-positive as well as gramnegative pathogenic strains. Namely, it inhibited B. cereus, E. coli, and S. Enteritidis at MICs of $256 \mu \mathrm{g} / \mathrm{ml}$ and L. monocytogenes at MIC of $512 \mu \mathrm{g} / \mathrm{ml}$.

Additionally, there were five more plant extracts exerting moderate activity $(\mathrm{MIC}=256 \mu \mathrm{g} / \mathrm{ml})$ against a single gramnegative strain (Table 2). Namely, Bauhinia malabarica Roxb. (Leguminosae) (bark), Breynia vitis-idaea (Burm.f.) C.E.C.Fisch. (Phyllanthaceae), Melastoma dodecandrum Lour. (Melastomataceae) (bark), and Picrasma javanica Blume (Simaroubaceae) inhibited E. coli; B. vitis-idaea (Burm.f.)
C.E.C.Fisch. inhibited S. Typhimurium; and Acalypha grandis Benth. (Euphorbiaceae) inhibited V. parahaemolyticus. Finally, Aganonerion polymorphum Spire (Apocynaceae), Diplazium esculentum (Retz.) Sw. (Athyriaceae), Ehretia microphylla Lam. (Boraginaceae), Ixora nigricans R.Br. ex Wight and Arn. (Rubiaceae), Lagerstroemia cochinchinensis Pierre ex Gagnep. (Lythraceae), Melastoma dodecandrum Lour. (Melastomataceae) (leaves with flower buds), and Melastoma saigonense (Kuntze) Merr. (Melastomataceae) (leaves with flower buds) produced only weak inhibitory actions at MICs of $512 \mu \mathrm{g} / \mathrm{ml}$ (Table 2 ).

The remaining 19 extracts of Acanthus ebracteatus Vahl (Acanthaceae), Aporosa villosa (Lindl.) Baill. (Phyllanthaceae), Artocarpus elasticus Reinw. ex Blume (Moraceae), Artocarpus odoratissimus Blanco (Moraceae), B. malabarica Roxb. (leaves), Breynia cernua (Poir.) Müll.Arg. (Phyllantaceae), Commelina communis L. (Commelinaceae), Cyathula prostrata (L.) Blume (Amaranthaceae), Emilia sonchifolia (L.) DC. ex DC. (Compositae), Helicteres angustifolia L. (Malvaceae), Hyptis capitata Jacq. (Lamiaceae), Kyllinga brevifolia Rottb. (Cyperaceae), Leea indica (Burm. f.) Merr. (Vitaceae), M. saigonense (Kuntze) Merr. (wooden stem and leaves), Parkia javanica (Lam.) Merr. (Leguminosae), Pseudelephantopus spicatus (Juss. ex Aubl.) Rohr (Compositae), Rourea minor (Gaertn.) Alston (Connaraceae), Tabernaemontana pandacaqui Lam. (Apocynaceae), and Triumfetta bartramia L. (Malvaceae) did not show any inhibitory action; thus, they have not been further discussed.

\section{Beneficial Gut Bacteria}

Subsequently, 16 extracts that exerted growth-inhibitory effect against diarrheagenic pathogens were verified for their safety to beneficial bacteria. The final MICs are presented in Table 2. Five extracts, namely, B. malabarica Roxb., B. vitis-idaea (Burm.f.) C.E.C.Fisch, D. esculentum (Retz.) Sw., L. cochinchinensis Pierre ex Gagnep., and $M$. dodecandrum Lour. (bark), did not have any inhibition of these strains (MICs $>512 \mu \mathrm{g} / \mathrm{ml}$ ), suggesting their harmless effect on gut commensals.

The remaining 11 extracts affected to some degree the growth of beneficial gut bacteria, particularly of bifidobacteria and $L$. casei (Table 2). The single strain was inhibited by $P$. siamensis (Miq.) Kurz (L. casei) and leaf with flower bud of $M$. dodecandrum Lour. (B. adolescentis) at MICs of 256 and $512 \mu \mathrm{g} / \mathrm{ml}$, respectively. Moreover, $P$. javanica Blume inhibited B. breve $(\mathrm{MIC}=128 \mu \mathrm{g} / \mathrm{ml})$ and $L$. casei $(\mathrm{MIC}=512 \mu \mathrm{g} / \mathrm{ml})$. Although $A$. polymorphum Spire significantly affected the growth of $B$. adolescentis $(\mathrm{MIC}=64 \mu \mathrm{g} / \mathrm{ml}$ ), the remaining probiotic strains were rather resistant toward this extract (MICs $\geq 512 \mu \mathrm{g}$ / $\mathrm{ml}$ ). Three and four probiotic bacteria were inhibited (MICs = $256-512 \mu \mathrm{g} / \mathrm{ml}$ ) by $A$. camansi Blanco and $M$. saigonense (Kuntze) Merr., respectively. At MICs ranging from 128 to $512 \mu \mathrm{g} / \mathrm{ml}$ (Table 2), E. microphylla Lam. and I. nigricans R.Br. ex Wight and Arn. affected the growth of the majority of beneficial strains. Although half of the bacteria were not inhibited by $A$. grandis Benth., this extract inhibited $B$. breve at low MIC $(64 \mu \mathrm{g} / \mathrm{ml})$. Finally, all six strains were inhibited by $A$. blancoi (Elmer) Merr. and A. tectorius (Lour.) Merr. Whereas the 
former uniformly affected the growth at very low MICs $(16 \mu \mathrm{g} /$ $\mathrm{ml})$, the latter inhibited $B$. breve (MIC $=64 \mu \mathrm{g} / \mathrm{ml}$ ) only.

\section{Cytotoxic Effect}

The outcomes of the MTT assay for all 16 antibacterially active plant extracts against normal and cancer intestinal cells are presented in Table 2. With the exception of D. esculentum (Retz.) Sw. $\left(\mathrm{IC}_{50}\right.$ values $>512 \mu \mathrm{g} / \mathrm{ml}$ ), all the 16 extracts produced a certain antiproliferative effect on at least one of the tested cell lines $\left(\mathrm{IC}_{50}\right.$ values $=33.82 \pm 10.57-368.07 \pm$ $30.00 \mu \mathrm{g} / \mathrm{ml})$.

\section{Normal Intestinal Cells}

Considering the toxicity to normal intestinal cells (FHs 74 Int), $M$. dodecandrum Lour. (bark) and P. siamensis (Miq.) Kurz did not show inhibitory action at the concentrations tested $\left(\mathrm{IC}_{50}>\right.$ $512 \mu \mathrm{g} / \mathrm{ml}$ ) (Table 2). Moderate toxicity was shown by $A$. polymorphum Spire, A. grandis Benth., A. blancoi (Elmer) Merr., B. malabarica Roxb., E. microphylla Lam., I. nigricans R.Br. ex Wight and Arn., L. cochinchinensis Pierre ex Gagnep., $M$. dodecandrum Lour. (leaves with flower buds), M. saigonense (Kuntze) Merr., and $P$. javanica Blume at $\mathrm{IC}_{50}$ values ranging from $118.76 \pm 36.04$ to $368.07 \pm 30.00 \mu \mathrm{g} / \mathrm{ml}$. Finally, the extracts of A. tectorius (Lour.) Merr., A. camansi Blanco, and B. vitis-idaea (Burm.f.) C.E.C.Fisch. were shown to be cytotoxic $\left(\mathrm{IC}_{50}\right.$ values $=$ $45.50 \pm 7.29,68.23 \pm 12.39$ and $68.75 \pm 8.89 \mu \mathrm{g} / \mathrm{ml}$, respectively)

\section{Cancer Intestinal Cells}

Regarding the antiproliferative activities against cancer intestinal cells (Table 2), the plants producing strong effects on Caco-2 $\left(\mathrm{IC}_{50}\right.$ values $\left.=33.82 \pm 10.57-87.40 \pm 19.18 \mu \mathrm{g} / \mathrm{ml}\right)$ have been ordered as follows: A. tectorius (Lour.) Merr., A. camansi Blanco, E. microphylla Lam., M. dodecandrum Lour. (leaves with flower buds), A. grandis Benth., A. blancoi (Elmer) Merr., and $M$. saigonense (Kuntze) Merr. With the exception of moderately cytotoxic E. microphylla Lam. and M. dodecandrum Lour. (leaves with flower buds), the same plant extracts with the addition of $B$. malabarica Roxb., B. vitis-idaea (Burm.f.) C.E.C.Fisch., $L$. cochinchinensis Pierre ex Gagnep., and P. siamensis (Miq.) Kurz also produced strong antiproliferative effect on HT-29 $\left(\mathrm{IC}_{50}\right.$ values $\left.=35.195 \pm 5.32-96.53 \pm 12.41 \mu \mathrm{g} / \mathrm{ml}\right)($ Table 2$)$. A moderate cytotoxic effect on both these cancer cell lines was then shown by A. polymorphum Spire, I. nigricans R.Br. ex Wight and Arn., M. dodecandrum Lour. (bark), and P. javanica Blume $\left(\mathrm{IC}_{50}\right.$ values $\left.=121.26 \pm 15.34-248.56 \pm 23.13 \mu \mathrm{g} / \mathrm{ml}\right)$. The majority of extracts revealed higher activities against Caco-2 than that of 5 -fluorouracil $\left(\mathrm{IC}_{50}=181.79 \pm 151.51 \mu \mathrm{g} / \mathrm{ml}\right)$.

\section{Selective Toxicity}

The calculated mean values for pathogenic/beneficial bacteria, cancer cells $\left(\bar{x}\right.$-MIC, $\bar{x}-\mathrm{IC}_{50}$, and $\bar{x}$-IC $\left.\mathrm{IC}_{80}\right)$, and derived SIs are presented in Table 2. Comparing the concentrations inhibiting $80 \%$ of growth for pathogenic bacteria and normal intestinal cells, the antibacterially active extracts were shown to be relatively safe (SIa values $=0.02-0.2 ; \mathrm{IC}_{80}$ values $>512 \mu \mathrm{g} / \mathrm{ml}$ ) except $A$. camansi Blanco (SIa $=-0.49 ; \mathrm{IC}_{80}=264.64 \pm 6.82 \mu \mathrm{g} / \mathrm{ml}$ ). Selective antibacterial effect $(\mathrm{SIb}$ values $=0.1)$ with relative safety for beneficial strains was shown by $B$. malabarica Roxb., $B$. vitisidaea (Burm.f.) C.E.C.Fisch., and P. siamensis (Miq.) Kurz (Table 2). However, none of the selective effects were as significant as in the case of ciprofloxacin $(\mathrm{SIb}=1.2)$. Other extracts did not show any noticeable selectivity or were comparably more harmful to beneficial bacteria, especially $A$. blancoi (Elmer) Merr., and $A$. tectorius (Lour.) Merr. (SIb values = -1.6 and -0.6 , respectively). Regarding the selective antiproliferative effects against cancer intestinal cells, $A$. blancoi (Elmer) Merr., E. microphylla Lam., L. cochinchinensis Pierre ex Gagnep., M. dodecandrum Lour. (bark), and $M$. saigonense (Kuntze) Merr. revealed higher selectivity (SIc values $=0.5-0.7)$ than that of 5 -fluorouracil $($ SIc $=0.4)$ (Table 2). Other extracts produced either the same or lower degree of selective effects than that of this cytotoxic drug, whereas A. tectorius (Lour.) Merr., B. malabarica Roxb., and B. vitis-idaea (Burm.f.) C.E.C.Fisch. were relatively more toxic to normal intestinal cells (SIc values $=-0.9$ to -0.1 ). The probiotic strains were not affected by the antiproliferative concentrations of $A$. polymorphum Spire (SId =0.13), mainly because of moderate inhibition of HT-29 $\left(\mathrm{IC}_{80}=130.50 \pm\right.$ $12.06 \mu \mathrm{g} / \mathrm{ml}$ ) (Table 2). Interestingly, the extract of $P$. siamensis (Miq.) Kurz produced noticeable selective actions combining antibacterial and antiproliferative effects on pathogenic bacteria and intestinal cancer cells without affecting beneficial bacteria and normal intestinal cells.

\section{DISCUSSION}

In the present study, 16 of 35 tested extracts revealed in vitro growth-inhibitory effect on the diarrheagenic bacterial pathogens, especially A. blancoi (Elmer) Merr., A. camansi Blanco, A. tectorius (Lour.) Merr., and P. siamensis (Miq.). Except A. camansi Blanco, the antibacterially active concentrations of the three were nontoxic to normal intestinal cells. Among the 16 extracts, A. blancoi (Elmer) Merr., E. microphylla Lam., L. cochinchinensis Pierre ex Gagnep., $M$. saigonense (Kuntze) Merr., and P. siamensis (Miq.) Kurz also revealed a strong selective antiproliferative effect against intestinal cancer lines. The extract of P. siamensis (Miq.) Kurz exhibited activities combining selective inhibition of pathogenic bacteria and intestinal cancer cells without affecting beneficial bacteria and normal intestinal cells. To the best of our knowledge, this is the first study on antibacterial and antiproliferative activities of A. polymorphum Spire, B. vitis-idaea (Burm.f.) C.E.C.Fisch., I. nigricans R.Br. ex Wight and Arn., L. cochinchinensis Pierre ex Gagnep., P. siamensis (Miq.) Kurz, and $M$. saigonense (Kuntze) Merr. Moreover, there are no previous studies on the cytotoxic effects of A. blancoi (Elmer) Merr. Although the cytotoxic effect of products isolated from $B$. malabarica Roxb. was described previously (Kittakoop et al., 2000), its antibacterial activity is herein reported for the first time. Our results correspond with those of previous studies on antibacterial and antiproliferative activities of $A$. grandis Benth. (Bradacs et al., 2009), D. esculentum (Retz.) Sw. (Mackeen et al., 1997; Rahmat et al., 2003), and P. javanica Blume (Khan et al., 
2001; Win et al., 2015). The above highlighted seven plant extracts with promising activities have mainly been discussed.

Two of the four tested species of the genus Artocarpus (Moraceae), namely, A. blancoi (Elmer) Merr. and A. camansi Blanco, exhibited strong antibacterial and antiproliferative activities in our study. Artocarpus spp. are rich in phenolic compounds, such as flavonoids, stilbenoids, and arylbenzofurans, which are known to possess a wide range of biological activities, including antibacterial and anticancer effects (Hafid et al., 2017). Our study is the first to report on anticlostridial activities of Artocarpus spp. As flavonoids have been reported to have potent in vitro inhibitory effect on some clostridia (Wu et al., 2013), these compounds might be responsible for significant antibacterial activities revealed by $A$. blancoi (Elmer) Merr. and A. camansi Blanco against C. difficile and C. perfringens. Beloy et al. (1976) isolated the flavonoid $5,7,4^{\prime}$-trihydroxyflavanone-3-O- $\alpha$-L-rhamnopyranoside from the bark extract of $A$. blancoi (Elmer) Merr., showing antibacterial activity against Mycobacterium tuberculosis. Ante et al. (2016) showed that bark essential oil of A. camansi Blanco produced antibacterial activity against some diarrheagenic bacteria. Our results show that both of these plants inhibited gram-positive bacteria only. Beside their anticlostridial effect, this selectivity probably also contributed to their relative toxicity to beneficial bacteria. In vitro inhibitory effect against lactobacilli was previously reported for Artocarpus lacucha Buch.-Ham. (Teanpaisan et al., 2014). An example of a compound isolated from the plant of this genus and showing similar activities is artocarpin. In the study by Sato et al. (1996), this flavonoid exhibited strong inhibition of all gram-positive bacteria, including L. casei, whereas in another study, it produced higher MICs against E. coli and Pseudomonas aeruginosa (Septama and Panichayupakaranant, 2015). The absence of antibacterial action of $A$. odoratissimus Blanco found herein will correlate with rather low levels of phenolic content detected in its fruit methanolic extract (Abu Bakar et al., 2015), compared to antibacterially active species (Jalal et al., 2015). Although hexane bark extract of A. elasticus Reinw. ex Blume exhibited activity against $B$. cereus and $E$. coli in the study by Ramli et al. (2016), its lack of activity in the present study could be influenced by the use of different extraction procedures. According to our results, A. blancoi (Elmer) Merr. and $A$. camansi Blanco had a selective cytotoxic effect on intestinal cancer cells, whereas the former did not show cytotoxicity to normal cells at the inhibitory concentrations against several pathogens. Various terpenoids and phytosterols were previously isolated from methanolic and dichloromethane extract of stem and leaves of $A$. camansi Blanco, respectively. Among them, friedelinol, cycloartenol, and cycloartenol acetate inhibited the growth of HT-29 cells; squalene has profound chemopreventive activity against colon carcinogenesis; and $\beta$ sitosterol has been shown to induce apoptosis in human colon tumors (Tsai et al., 2013). Regarding cytotoxic compounds isolated from other Artocarpus spp., the prenylated flavone artelastin revealed strong in vitro activity against five colon cancer cell lines (COLO 205, HCT 116, HCT 15, HT-29, and SW 620) in the study by Pedro et al. (2005).
Similar to Artocarpus spp., the leaf extract of A. tectorius (Lour.) Merr. exhibited growth-inhibitory effects only against gram-positive bacteria. This corresponds with the study by Wiart et al. (2004), where its methanolic leaf extract produced antibacterial activity against $B$. cereus but not $E$. coli. We also found that the overall cytotoxic effect of this plant was strong. Although the antiproliferative effect on cancer cells was not selective, the extract concentrations inhibiting the pathogens were generally nontoxic to normal intestinal cells. Previous phytochemical analysis of leaf ethanolic/methanolic extracts of this plant showed the presence of various naphthylisoquinoline alkaloids, such as 7-epiancistrobrevine $\mathrm{D}$, ancistrocladinine, ancistrotectoquinone A-B, ancistrotectoriline $\mathrm{A}-\mathrm{C}$, and hamatinine (Anh et al., 1997; Tang et al., 2000; Tang et al., 2010; Bringmann et al., 2016). Since these isoquinoline alkaloids are known to possess various biological activities, including antimicrobial and cytotoxic effects, we suspect them to be responsible for the growth-inhibitory effects revealed by $A$. tectorius (Lour.) Merr. in the present study. For example, in the study by Mihalyi et al. (2014), michellamine B isolated from Ancistrocladus korupensis D.W.Thomas and Gereau inhibited B. subtilis. Jiang et al. (2013) showed that naphthylisoquinolines isolated from A. tectorius (Lour.) Merr. exhibited cytotoxic effect against three leukemia cells in vitro. In another study, 7epiancistrobrevine and ancistrotectoriline exhibited activity against pancreatic cancer cells (Shang et al., 2020). The present study is the first to report on in vitro selective antiproliferative activity of $A$. tectorius (Lour.) Merr. against intestinal cells.

Regarding $P$. siamensis (Miq.) Kurz, there are no comparable studies dealing with species of the same genus. However, our results showing a noticeable combination of selective antibacterial and cytotoxic effects of its bark extract can be compared to the data available for closely related genus Shorea (Dipterocarpaceae). For example, Marandi et al. (2016) showed that bark ethanolic extract from Indian antidiarrheal and antidysenteric medicinal plant Shorea robusta Gaertn. exhibited inhibitory action against B. cereus, B. subtilis, E. faecalis, E. coli, S. Typhi, and V. cholerae. Stilbene derivatives isolated from barks of Shorea spp. previously showed strong antibacterial effects against some of these strains (Nitta et al., 2002; Sudto et al., 2019). Some polyphenols, such as stilbenes, can inhibit several nonbeneficial bacteria from the human microbiota, with no noticeable effects on the growth of probiotic bacteria (Requena et al., 2010). Therefore, we suggest that some of these agents could also contribute to the selective antibacterial activities of $P$. siamensis (Miq.) Kurz shown in the present study. Regarding cytotoxic effect, oligostilbenoids were usually the constituents derived from Shorea spp., with reported antiproliferative action against various cancer cell lines (Rohaiza, 2011; Zawawi et al., 2012; Moriyama et al., 2016). Among them, ampelopsin E exhibited obvious antiproliferative properties on COLO205 and HT-29 cells (Tian et al., 2019), whereas $\alpha$-viniferin showed selective inhibition of colon cancer cells (HCT-116, HT29, and Caco-2) with twofold lower $\mathrm{IC}_{50}$ compared to normal colon cells (CCD-18Co) (Gonzalez-Sarrias et al., 2011). To identify phytochemicals responsible for the in vitro selective 
inhibitory actions shown by $P$. siamensis (Miq.) Kurz in the present study, an accurate chemical analysis of this plant is needed.

Finally, E. microphylla Lam., L. cochinchinensis Pierre ex Gagnep., and M. saigonense (Kuntze) Merr. revealed a strong selective antiproliferative effect against intestinal cancer lines. It has been reported that triterpenes urs-12-en-24-oic acid, 3-oxo-, methyl ester, and $\beta$-amyrin are involved in anticancer activities of products derived from leaves of E. microphylla Lam. (Rajkumar et al., 2019). Our study corresponds with other studies dealing with these chemicals. For example, in the study by Kuete et al. (2018), $\beta$-amyrin produced a selective cytotoxic effect against Caco-2 compared to that on normal cell line HEK293. In another study, extract of Alstonia macrophylla Wall. ex G.Don containing $\beta$-amyrin produced a selective cytotoxic effect against HT-29 compared to that on normal cell line HDFn (Tan et al., 2019). The present study is the first to report the antiproliferative activities of E. microphylla Lam. against intestinal cell lines. Compounds such as triterpenes, tannins, ellagic acids, glycosides, and flavones were previously attributed to bioactive properties of Lagerstroemia spp. (Chan et al., 2014). In previous studies, triterpenes isolated from species of this genus produced significant in vitro activity against colon cancer cells, for instance, betulinic acid and $3 \beta$ acetoxyolean-12-en-28-acid against HCT15 (Woo et al., 2016) and corosolic acid against HCT116 (Sung et al., 2014). Regarding M. saigonense (Kuntze) Merr., there are various previously published studies on related species showing corresponding results. For example, the methanolic leaf extract of Melastoma malabathricum L. produced an antiproliferative effect on HT-29 in the study by Kamsani et al. (2019). Asiatic acid, caffeic acid, p-coumaric acid, kaempferol, quercetin, rutin, and ursolic acid were isolated compounds with previously profound antiproliferative action to this cell line. In the study by Karakurt et al. (2020), p-coumaric acid exhibited selective inhibition of Caco-2 and HT-29 cells compared to that of healthy colon epithelial cells (CCD-18Co). Since the decoction from the leaves of $M$. malabathricum $\mathrm{L}$. is also traditionally consumed to treat diarrhea, we suggest a similar composition of bioactive compounds to be present in M. saigonense (Kuntze) Merr. (Ong and Nordiana, 1999). Regarding the moderate selective antiproliferative activities of bark and leaf with flower bud extracts of $M$. dodecandrum Lour., three pentacyclic triterpenoids (ursolic acid, asiatic acid, and terminolic acid) and one tannin (casuarinin) were previously isolated from this plant and found to significantly decrease interleukin-8 production in HT-29 (Yang et al., 2014).

In summary, A. blancoi (Elmer) Merr., A. tectorius (Lour.) Merr., and P. siamensis (Miq.) Kurz produced significant growthinhibitory effects against diarrheagenic bacterial pathogens at concentrations nontoxic to normal intestinal cells. Except the strong anticlostridial actions of A. blancoi (Elmer) Merr., the MICs determined for these plant extracts in the present study reflect rather moderate antibacterial activities. However, the discrimination of specific cell toxicity indicates that higher amounts of these products necessary to acquire the appropriate efficiency may still be safe to use (Cos et al., 2006). A long tradition of their use in folk medicinal systems supports this assumption. Moreover, it has been reported that microorganisms are less likely to develop resistance to phytochemicals with anti-infective potential, mainly because of their high diversity in plants. Some were even considered as antibiotic resistance modifying compounds (Sibanda and Okoh, 2007). Additionally, our study showed that the extract of $P$. siamensis (Miq.) Kurz was relatively safe for probiotic bacteria, and together with $A$. blancoi (Elmer) Merr., they exerted selective anticancer activities in vitro. Similar to the cytotoxic activities revealed by E. microphylla Lam., L. cochinchinensis Pierre ex Gagnep., and M. saigonense (Kuntze) Merr., the inhibitory effect of A. blancoi (Elmer) Merr. on cancer cell line Caco-2 and the selectivity of its overall antiproliferative actions were generally higher than those of anticancer drug 5-fluorouracil.

These results suggest that extracts from the abovementioned Cambodian and Philippine plant species are promising materials for further research focused on the development of new plant-derived selective antibacterial and antiproliferative agents used in the treatment of infectious diarrhea and associated intestinal cancer diseases. For instance, the combination of strong anticlostridial and anticancer actions of A. blancoi (Elmer) Merr. may in the future be utilized in the treatment of digestive cancers associated with C. difficile infections (Han et al., 2013). However, further phytochemical and pharmacological research is needed for the isolation and proper identification of their bioactive constituents. Referring to studies dealing with taxonomically related plants to estimate the presence of their bioactive principles is a very limited approach as their composition can vary greatly. On the other hand, our results could serve as an indicator of bioactive potentials of products derived from species of the same taxa. This is mainly the case of P. siamensis (Miq.) Kurz that exhibited selective inhibition of pathogenic bacteria and intestinal cancer cells without affecting beneficial bacteria and normal intestinal cells. Future research combining the ethnomedicinal and chemotaxonomic approaches might help to identify more plants with promising bioactivities (Hao and Xiao, 2020).

\section{DATA AVAILABILITY STATEMENT}

The original contributions presented in the study are included in the article/Supplementary Material; further inquiries can be directed to the corresponding author.

\section{AUTHOR CONTRIBUTIONS}

TK collected the plant materials, coordinated antibacterial activity testing and its related data analysis, and prepared the article. $\mathrm{BF}$ and $\mathrm{MK}$ processed the voucher specimens and participated in the collection of plant materials and testing of antibacterial activity. ID conducted the cytotoxicity assays and their related data analysis. HS was responsible for maintenance and culturing of anaerobic bacteria tested. ET and $\mathrm{MB}$ participated in the collection of plant materials and 
verification of the data on the ethnobotanical use of plants in the Philippines. SN participated in the collection of plant materials and verification of the data on the ethnobotanical use of plants in Cambodia. LK conceptualized and coordinated the whole study and provided the botanical identification of plant samples. All authors have read and agreed to the published version of the article.

\section{REFERENCES}

Abu Bakar, M. F., Abdul Karim, F., and Perisamy, E. (2015). Comparison of Phytochemicals and Antioxidant Properties of Different Fruit Parts of Selected Artocarpus Species from Sabah, Malaysia. Sains Malays 44 (3), 355-363. doi:10.17576/jsm-2015-4403-06

Anh, N. H., Porzel, A., Ripperger, H., Bringmann, G., Schäffer, M., God, R., et al. (1997). Naphthylisoquinoline Alkaloids from Ancistrocladus cochinchinensis. Phytochemistry 45 (6), 1287-1291. doi:10.1016/s0031-9422(97)00110-6

Ante, I., Aboaba, S., Siddiqui, H., and Choudhary, M. I. (2016). Essential Oils of the Leaf, Stem-Bark, and Nut of Artocarpus camansi: Gas Chromatography-Mass Spectrometry Analysis and Activities against Multidrug-Resistant Bacteria. J. Herbs, Spices Med. Plants 22 (3), 203-210. doi:10.1080/ 10496475.2016.1159638

Batalha, P. N., Vieira de Souza, M. C., Peña-Cabrera, E., Cruz, D. C., and da Costa Santos Boechat, F. (2016). Quinolones in the Search for New Anticancer Agents. Curr. Pharm. Des. 22 (39), 6009-6020. doi:10.2174/ 1381612822666160715115025

Behnsen, J., Deriu, E., Sassone-Corsi, M., and Raffatellu, M. (2013). Probiotics: Properties, Examples, and Specific Applications. Cold Spring Harb. Perspect. Med. 3 (3), a010074. doi:10.1101/cshperspect.a010074

Beloy, F. B., Masilungan, V. A., Cruzde, la. R. M., and Ramos, E. V. (1976). Investigation of Some Philippine Plants for Antimicrobial Substances. Philipp. J. Sci. 105, 205-213.

Bradacs, G., Maes, L., and Heilmann, J. (2009). In Vitro Cytotoxic, Antiprotozoal and Antimicrobial Activities of Medicinal Plants from Vanuatu. Phytother. Res. 24 (6), 800-809. doi:10.1002/ptr.2981

Bringmann, G., Xu, M., Seupel, R., Feineis, D., and Wu, J. (2016). Ancistrotectoquinones $\mathrm{A}$ and $\mathrm{B}$, the First Quinoid Naphthylisoquinoline Alkaloids, from the Chinese Liana Ancistrocladus tectorius. Nat. Prod. Commun. 11 (7), 971-976. doi:10.1177/1934578x1601100725

Casburn-Jones, A. C., and Farthing, M. J. (2004). Management of Infectious Diarrhoea. Gut 53 (2), 296-305. doi:10.1136/gut.2003.022103

Chan, C.-L., Gan, R.-Y., Shah, N. P., and Corke, H. (2018). Polyphenols from Selected Dietary Spices and Medicinal Herbs Differentially Affect Common Food-Borne Pathogenic Bacteria and Lactic Acid Bacteria. Food Control 92, 437-443. doi:10.1016/j.foodcont.2018.05.032

Chan, E. W. C., Tan, L. N., and Wong, S. K. (2014). Phytochemistry and Pharmacology of Lagerstroemia Speciosa: a Natural Remedy for Diabetes. Int. J. Herb. Med. 2 (1), 81-87.

Chassagne, F., Hul, S., Deharo, E., and Bourdy, G. (2016). Natural Remedies Used by Bunong People in Mondulkiri Province (Northeast Cambodia) with Special Reference to the Treatment of 11 Most Common Ailments. J. Ethnopharmacol. 191, 41-70. doi:10.1016/j.jep.2016.06.003

Chea, A., Jonville, M. C., Bun, S. S., Laget, M., Elias, R., Duménil, G., et al. (2007). In Vitro antimicrobial Activity of Plants Used in Cambodian Traditional Medicine. Am. J. Chin. Med. 35 (05), 867-873. doi:10.1142/s0192415x07005338

Clinical and Laboratory Standards Institute (2021). Methods for Dilution Antimicrobial Susceptibility Tests for Bacteria that Grow Aerobically; Approved Standard-2021 Ed. CLSI Document M07-M100. Wayne: CLSI.

Cos, P., Vlietinck, A. J., Berghe, D. V., and Maes, L. (2006). Anti-infective Potential of Natural Products: How to Develop a Stronger In Vitro 'proof-Of-Concept'. J. Ethnopharmacol. 106, 290-302. doi:10.1016/j.jep.2006.04.003

de Guzman, G. Q., Dacanay, A. T., Andaya, B. A., and Alejandro, G. J. (2016). Ethnopharmacological Studies on the Uses of Euphorbia hirta in the Treatment of Dengue in Selected Indigenous Communities in Pangasinan (Philippines). J. Intercult. Ethnopharmacol. 5 (3), 239-243. doi:10.5455/jice.20160330124637

\section{FUNDING}

This work was supported by the Internal Grant Agency of the Faculty of Tropical AgriSciences (IGA 20213109), the METROFOOD-CZ Research Infrastructure Project (MEYS LM2018100), and the Strategic Setting of Human Resources Development at CZU (CZ.02.2.69/0.0/0.0/18_054/0014642).

de Padua, L. S., Bunyapraphatsara, N., and Lemmens, R. H. M. J. (1999). Plant Resources of South-East Asia (PROSEA) No 12 (1), Medicinal and Poisonous Plants 1. (Leiden: Backhuys Publishers).

Diniz-Santos, D. R., Silva, L. R., and Silva, N. (2006). Antibiotics for the Empirical Treatment of Acute Infectious Diarrhea in Children. Braz. J. Infect. Dis. 10 (3), 217-227. doi:10.1590/s1413-86702006000300011

Duriyaprapan, S., Tanpanich, S., and Khuankhamnuan, C. (2005). The Plant Resources of South-East Asia (PROSEA). Acta Hortic. 675, 15-21. doi:10.17660/actahortic.2005.675.1

Francino, M. P. (2015). Antibiotics and the Human Gut Microbiome: Dysbioses and Accumulation of Resistances. Front. Microbiol. 6, 1543. doi:10.3389/ fmicb.2015.01543

Fuente, B., López-García, G., Máñez, V., Alegría, A., Barberá, R., and Cilla, A. (2020). Antiproliferative Effect of Bioaccessible Fractions of Four Brassicaceae Microgreens on Human Colon Cancer Cells Linked to Their Phytochemical Composition. Antioxidants (Basel) 9 (5), 368. doi:10.3390/antiox9050368

Garrett, W. S. (2019). The Gut Microbiota and Colon Cancer. Science 364 (6446), 1133-1135. doi:10.1126/science.aaw2367

Gavrish, E., Shrestha, B., Chen, C., Lister, I., North, E. J., Yang, L., et al. (2014). In Vitro and In Vivo Activities of HPil, a Selective Antimicrobial against Helicobacter pylori. Antimicrob. Agents Chemother. 58 (6), 3255-3260. doi:10.1128/aac.02573-13

González-Sarrías, A., Gromek, S., Niesen, D., Seeram, N. P., and Henry, G. E. (2011). Resveratrol Oligomers Isolated from Carex Species Inhibit Growth of Human Colon Tumorigenic Cells Mediated by Cell Cycle Arrest. J. Agric. Food Chem. 59 (16), 8632-8638. doi:10.1021/jf201561e

Hafid, A. F., Aoki-Utsubo, C., Permanasari, A. A., Adianti, M., Tumewu, L., Widyawaruyanti, A., et al. (2017). Antiviral Activity of the Dichloromethane Extracts from Artocarpus heterophyllus Leaves against Hepatitis C Virus. Asian Pac. J. Trop. Biomed. 7 (7), 633-639. doi:10.1016/j.apjtb.2017.06.003

Han, X. H., Du, C. X., Zhang, C. L., Zheng, C. L., Wang, L., Li, D., et al. (2013). Clostridium difficile Infection in Hospitalized Cancer Patients in Beijing, China Is Facilitated by Receipt of Cancer Chemotherapy. Anaerobe 24, 82-84. doi:10.1016/j.anaerobe.2013.05.004

Hao, D.-c., and Xiao, P.-g. (2020). Pharmaceutical Resource Discovery from Traditional Medicinal Plants: Pharmacophylogeny and Pharmacophylogenomics. Chin. Herbal Medicines 12, 104-117. doi:10.1016/ j.chmed.2020.03.002

Hecht, D. W. (1999). "Antimicrobial Agents and Susceptibility Testing: Susceptibility Testing of Anaerobic Bacteria," in Manual of Clinical Microbiology. Editors P. R. Murray, E. J. Baron, M. A. Pfaller, F. C. Tenover, and R. H. Yolken. 7th ed (Washington DC: American Society for Microbiology ASM), 1555-1563.

Houdková, M., Urbanová, K., Doskočil, I., Rondevaldová, J., Nový, P., Nguon, S., et al. (2018). In Vitro Growth-Inhibitory Effect of Cambodian Essential Oils against Pneumonia Causing Bacteria in Liquid and Vapour Phase and Their Toxicity to Lung Fibroblasts. South Afr. J. Bot. 118, 85-97. doi:10.1016/ j.sajb.2018.06.005

Jalal, T. K., Ahmed, I. A., Mikail, M., Momand, L., Draman, S., Isa, M. L., et al. (2015). Evaluation of Antioxidant, Total Phenol and Flavonoid Content and Antimicrobial Activities of Artocarpus altilis (Breadfruit) of Underutilized Tropical Fruit Extracts. Appl. Biochem. Biotechnol. 175 (7), 3231-3243. doi:10.1007/s12010-015-1499-0

Jiang, C., Li, Z. L., Gong, P., Kang, S. L., Liu, M. S., Pei, Y. H., et al. (2013). Five Novel Naphthylisoquinoline Alkaloids with Growth Inhibitory Activities against Human Leukemia Cells HL-60, K562 and U937 from Stems and Leaves of Ancistrocladus tectorius. Fitoterapia 91, 305-312. doi:10.1016/ j.fitote.2013.09.010 
Kamsani, N. E., Zakaria, Z. A., Md Nasir, N. L., Mohtarrudin, N., and Mohamad Alitheen, N. B. (2019). Safety Assessment of Methanol Extract of Melastoma malabathricum L. Leaves Following the Subacute and Subchronic Oral Consumptions in Rats and its Cytotoxic Effect against the HT29 Cancer Cell Line. Evid. Based Complement. Alternat Med. 2019, 5207958. doi:10.1155/2019/5207958

Karakurt, S., Abuşoğlu, G., and Arituluk, Z. C. (2020). Comparison of Anticarcinogenic Properties of Viburnum opulus and its Active Compound P-Coumaric Acid on Human Colorectal Carcinoma. Turk. J. Biol. 44 (5), 252-263. doi:10.3906/biy-2002-30

Kelber, O., Steinhoff, B., Nauert, C., Biller, A., Adler, M., Abdel-Aziz, H., et al. (2016). Ethanol in Herbal Medicinal Products for Children : Data from Pediatric Studies and Pharmacovigilance Programs. Wien Med. Wochenschr. 167 (7-8), 183-188. doi:10.1007/s10354-016-0474-x

Kham, L. (2004). Medicinal Plants of Cambodia: Habitat, Chemical Constituents and Ethnobotanical Uses. Golden Square: Bendigo Scientific Press.

Khan, M. R., Kihara, M., and Omoloso, A. D. (2001). Antibacterial Activity of Picrasma javanica. Fitoterapia 72 (4), 406-408. doi:10.1016/s0367-326x(00) 00274-4

Kittakoop, P., Kirtikara, K., Tanticharoen, M., and Thebtaranonth, Y. (2000). Antimalarial Preracemosols A and B, Possible Biogenetic Precursors of Racemosol from Bauhinia malabarica Roxb. Phytochemistry 55 (4), 349-352. doi:10.1016/s0031-9422(00)00318-6

Kokoška, L., Klouček, P., Leuner, O., and Nový, P. (2019). Plant-Derived Products as Antibacterial and Antifungal Agents in Human Health Care. Curr. Med. Chem. 26 (29), 5501-5541. doi:10.2174/0929867325666180831144344

Kudera, T., Doskočil, I., Salmonová, H., Petrtýl, M., Skřivanová, E., and Kokoška, L. (2020). In Vitro Selective Growth-Inhibitory Activities of Phytochemicals, Synthetic Phytochemical Analogs, and Antibiotics against Diarrheagenic/ Probiotic Bacteria and Cancer/Normal Intestinal Cells. Pharmaceuticals (Basel) 13 (9), 233. doi:10.3390/ph13090233

Kuete, V., Ngnintedo, D., Fotso, G. W., Karaosmanoğlu, O., Ngadjui, B. T., Keumedjio, F., et al. (2018). Cytotoxicity of Seputhecarpan D, Thonningiol and 12 Other Phytochemicals from African Flora towards Human Carcinoma Cells. BMC Complement. Altern. Med. 18 (1), 36. doi:10.1186/s12906-0182109-9

Langenberger, G., Prigge, V., Martin, K., Belonias, B., and Sauerborn, J. (2008). Ethnobotanical Knowledge of Philippine Lowland Farmers and its Application in Agroforestry. Agrofor. Syst. 76 (1), 173-194. doi:10.1007/s10457-008-9189-3

Lemmens, R. H. M. J. L., and Bunyapraphatsara, N. (2003). Plant Resources of South-East Asia (PROSEA) No 12 (3), Medicinal and Poisonous Plants 3. Leiden: Backhuys Publishers.

Lim, T. K. (2012). Edible Medicinal and Non Medicinal Plants. Fruits. New York: Springer.

Lin, J. P., Yang, J. S., Wu, C. C., Lin, S. S., Hsieh, W. T., Lin, M. L., et al. (2008). Berberine Induced Down-Regulation of Matrix Metalloproteinase-1, -2 and -9 in Human Gastric Cancer Cells (SNU-5). In Vivo 22 (2), 223-230.

Mackeen, M. M., Ali, A. M., El-Sharkawy, S. H., Manap, M. Y., Salleh, K. M., Lajis, N. H., et al. (1997). Antimicrobial and Cytotoxic Properties of Some Malaysian Traditional Vegetables (Ulam). Int. J. Pharmacognosy 35 (3), 174-178. doi:10.1076/phbi.35.3.174.13294

Maher, S., and McClean, S. (2006). Investigation of the Cytotoxicity of Eukaryotic and Prokaryotic Antimicrobial Peptides in Intestinal Epithelial Cells In Vitro. Biochem. Pharmacol. 71 (9), 1289-1298. doi:10.1016/j.bcp.2006.01.012

Marandi, R. R., Britto, S. J., and Soreng, P. K. (2016). Phytochemical Profiling, Antibacterial Screening and Antioxidant Properties of the Sacred Tree (Shorea robusta Gaertn.) of Jharkhand. Int. J. Pharm. Sci. Res. 7 (7), 2874-2888. doi:10.13040/IJPSR.0975-8232.7(7).2874-88

Meng, C. Y., Smith, B. L., Bodhidatta, L., Richard, S. A., Vansith, K., Thy, B., et al. (2011). Etiology of Diarrhea in Young Children and Patterns of Antibiotic Resistance in Cambodia. Pediatr. Infect. Dis. J. 30 (4), 331-335. doi:10.1097/ inf.0b013e3181fb6f82

Mihalyi, A., Jamshidi, S., Slikas, J., and Bugg, T. D. (2014). Identification of Novel Inhibitors of Phospho-MurNAc-Pentapeptide Translocase MraY from Library Screening: Isoquinoline Alkaloid Michellamine B and Xanthene Dye Phloxine B. Bioorg. Med. Chem. 22 (17), 4566-4571. doi:10.1016/j.bmc.2014.07.035

Moriyama, H., Moriyama, M., Ninomiya, K., Morikawa, T., and Hayakawa, T. (2016). Inhibitory Effects of Oligostilbenoids from the Bark of Shorea roxburghii on Malignant Melanoma Cell Growth: Implications for Novel Topical Anticancer Candidates. Biol. Pharm. Bull. 39 (10), 1675-1682. doi:10.1248/bpb.b16-00420

Mosmann, T. (1983). Rapid Colorimetric Assay for Cellular Growth and Survival: Application to Proliferation and Cytotoxicity Assays. J. Immunol. Methods 65 (1-2), 55-63. doi:10.1016/0022-1759(83)90303-4

Neftel, K. A., and Hübscher, U. (1987). Effects of Beta-Lactam Antibiotics on Proliferating Eucaryotic Cells. Antimicrob. Agents Chemother. 31 (11), 1657-1661. doi:10.1128/aac.31.11.1657

Nitta, T., Arai, T., Takamatsu, H., Inatomi, Y., Murata, H., Iinuma, M., et al. (2002). Antibacterial Activity of Extracts Prepared from Tropical and Subtropical Plants on Methicillin-Resistant Staphylococcus aureus. J. Health Sci. 48 (3), 273-276. doi:10.1248/jhs.48.273

Novaková, J., Vlková, E., Bonušova, B., Rada, V., and Kokoška, L. (2013). In Vitro Selective Inhibitory Effect of 8-Hydroxyquinoline against Bifidobacteria and Clostridia. Anaerobe 22, 134-136. doi:10.1016/j.anaerobe.2013.05.008

Ong, H. C., and Nordiana, M. (1999). Malay Ethno-Medico Botany in Machang, Kelantan, Malaysia. Fitoterapia 70 (5), 502-513. doi:10.1016/s0367-326x(99) 00077-5

Onoda, T., Ono, T., Dhar, D. K., Yamanoi, A., and Nagasue, N. (2005). Tetracycline Analogues (Doxycycline and COL-3) Induce Caspase-dependent and -independent Apoptosis in Human Colon Cancer Cells. Int. J. Cancer 118 (5), 1309-1315. doi:10.1002/ijc.21447

Our World in Data (2011). Diarrheal Diseases. Available at: https:// ourworldindata.org/diarrheal-diseases (Accessed October 19, 2020).

Palombo, E. A. (2006). Phytochemicals from Traditional Medicinal Plants Used in the Treatment of Diarrhoea: Modes of Action and Effects on Intestinal Function. Phytother Res. 20 (9), 717-724. doi:10.1002/ptr.1907

Pedro, M., Ferreira, M. M., Cidade, H., Kijjoa, A., Bronze-da-Rocha, E., and Nascimento, M. S. (2005). Artelastin Is a Cytotoxic Prenylated Flavone that Disturbs Microtubules and Interferes with DNA Replication in MCF-7 Human Breast Cancer Cells. Life Sci. 77 (3), 293-311. doi:10.1016/j.lfs.2004.09.049

Rahmat, A., Kumar, V., Fong, L. M., Endrini, S., and Sani, H. A. (2003). Determination of Total Antioxidant Activity in Three Types of Local Vegetables Shoots and the Cytotoxic Effect of Their Ethanolic Extracts against Different Cancer Cell Lines. Asia Pac. J. Clin. Nutr. 12 (3), 292-295.

Rajković, A., Jovanović, J., Monteiro, S., Decleer, M., Andjelković, M., Foubert, A., et al. (2020). Detection of Toxins Involved in Foodborne Diseases Caused by Gram-Positive Bacteria. Compr. Rev. Food Sci. Food Saf. 19 (4), 1605-1657. doi:10.1111/1541-4337.12571

Rajkumar, R., Shivakumar, M. S., Senthil Nathan, S., and Selvam, K. (2019). Preparation and Characterization of Chitosan Nanocomposites Material Using Silver Nanoparticle Synthesized Carmona retusa (Vahl) Masam Leaf Extract for Antioxidant, Anti-Cancerous and Insecticidal Application. J. Clust. Sci. 30 (4), 1145-1155. doi:10.1007/s10876-019-01578-9

Ramli, F., Rahmani, M., Ismail, I. S., Sukari, M. A., Abd Rahman, M., Zajmi, A., et al. (2016). A New Bioactive Secondary Metabolite from Artocarpus elasticus. Nat. Prod. Commun. 11 (8), 1103-1106. doi:10.1177/1934578x1601100818

Rathee, D., Rathee, P., Rathee, S., and Rathee, D. (2016). Phytochemical Screening and Antimicrobial Activity of Picrorrhiza kurroa, an Indian Traditional Plant Used to Treat Chronic Diarrhea. Arabian J. Chem. 9, S1307-S1313. doi:10.1016/j.arabjc.2012.02.009

Rawla, P., Sunkara, T., and Barsouk, A. (2019). Epidemiology of Colorectal Cancer: Incidence, Mortality, Survival, and Risk Factors. Prz. Gastroenterol. 14 (2), 89-103. doi:10.5114/pg.2018.81072

Requena, T., Monagas, M., Pozo-Bayón, M. A., Martín-Álvarez, P. J., Bartolomé, B., del Campo, R., et al. (2010). Perspectives of the Potential Implications of Wine Polyphenols on Human Oral and Gut Microbiota. Trends Food Sci. Tech. 21 (7), 332-344. doi:10.1016/j.tifs.2010.04.004

Rogowski, W., and Sulżyc-Bielicka, V. (2016). Optimal Duration of a First-Line Palliative Chemotherapy in Disseminated Colorectal Cancer - a Review of the Literature from a Developing Country Perspective. Contemp. Oncol. (Pozn) 20, 210-214. doi:10.5114/wo.2016.61561

Rohaiza, S. (2011). Cytotoxic Oligostilbenes from Shorea hopeifolia. Afr. J. Pharm. Pharmacol. 5 (10), 1272-1277. doi:10.5897/ajpp10.386

Sato, M., Fujiwara, S., Tsuchiya, H., Fujii, T., Iinuma, M., Tosa, H., et al. (1996). Flavones with Antibacterial Activity against Cariogenic Bacteria. J. Ethnopharmacol. 54 (2-3), 171-176. doi:10.1016/s0378-8741(96)01464-X 
Septama, A. W., and Panichayupakaranant, P. (2015). Synergistic Effect of Artocarpin on Antibacterial Activity of Some Antibiotics against Methicillin-Resistant Staphylococcus aureus, Pseudomonas aeruginosa, and Escherichia coli. Pharm. Biol. 54 (4), 686-691. doi:10.3109/13880209.2015.1072566

Shang, X. F., Yang, C. J., Morris-Natschke, S. L., Li, J. C., Yin, X. D., Liu, Y. Q., et al. (2020). Biologically Active Isoquinoline Alkaloids Covering 2014-2018. Med. Res. Rev. 40 (6), 2212-2289. doi:10.1002/med.21703

Sibanda, T., and Okoh, A. I. (2007). The Challenges of Overcoming Antibiotic Resistance: Plant Extracts as Potential Sources of Antimicrobial and Resistance Modifying Agents. Afr. J. Biotechnol. 6 (25), 2886-2896.

Srisawat, T., Chumkaew, P., Heed-Chim, W., Sukpondma, Y., and Kanokwiroon, K. (2013). Phytochemical Screening and Cytotoxicity of Crude Extracts of Vatica diospyroides Symington Type LS. Trop. J. Pharm. Res. 12 (1), 71-76. doi:10.4314/tjpr.v12i1.12

Stuart, G. U., Jr. (2017). List of Philippine Herbal Medicinal Plants. Philippine medicinal plants. StuartXchange-SX. Available at: http://www.stuartxchange. org/CompleteList.html (Accessed February 20, 2017).

Sudto, K., Saparpakorn, P., Tancharoen, C., Phromyothin, D., Techasakul, S., Khunnawutmanotham, N., et al. (2019). Diptoindonesin D, a Potent Antibacterial Activity against Gram-Positive Bacteria, an Inhibitor of Penicillin-Binding Protein 2a from the Stem Bark of Shorea roxburghii G.Don. Chiang Mai J. Sci. 46 (6), 1161-1175.

Sun, X., Gao, Y., Wang, X., Hu, G., Wang, Y., Feng, B., et al. (2018). Escherichia coli O101-Induced Diarrhea Develops Gut Microbial Dysbiosis in Rats. Exp. Ther. Med. 17 (1), 824-834. doi:10.3892/etm.2018.6997

Sung, B., Kang, Y. J., Kim, D. H., Hwang, S. Y., Lee, Y., Kim, M., et al. (2014). Corosolic Acid Induces Apoptotic Cell Death in HCT116 Human Colon Cancer Cells through a Caspase-dependent Pathway. Int. J. Mol. Med. 33 (4), 943-949. doi:10.3892/ijmm.2014.1639

Taddese, R., Garza, D. R., Ruiter, L. N., de Jonge, M. I., Belzer, C., Aalvink, S., et al. (2020). Growth Rate Alterations of Human Colorectal Cancer Cells by 157 Gut Bacteria. Gut Microbes 12 (1), 1-20. doi:10.1080/19490976.2020.1799733

Tan, M. C. S., Carranza, M. S. S., Linis, V. C., Malabed, R. S., and Oyong, G. G. (2019). Antioxidant, Cytotoxicity, and Antiophidian Potential of Alstonia macrophylla Bark. ACS Omega 4 (5), 9488-9496. doi:10.1021/ acsomega.9b00082

Tan, M. L. (1980). Philippine Medicinal Plants in Common Use. (Quezon City: AKAP).

Tang, C. P., Xin, Z. Q., Li, X. Q., and Ye, Y. (2010). Two New Naphthylisoquinoline Alkaloids from Stems and Leaves of Ancistrocladus tectorius. Nat. Prod. Res. 24 (11), 989-994. doi:10.1080/14786410902836727

Tang, C. P., Yang, Y. P., Zhong, Y., Zhong, Q. X., Wu, H. M., and Ye, Y. (2000). Four New Naphthylisoquinoline Alkaloids from Ancistrocladus tectorius. J. Nat. Prod. 63 (10), 1384-1387. doi:10.1021/np000091d

Teanpaisan, R., Senapong, S., and Puripattanavong, J. (2014). In Vitro Antimicrobial and Antibiofilm Activity of Artocarpus lakoocha (Moraceae) Extract against Some Oral Pathogens. Trop. J. Pharm. Res. 13 (7), 1149. doi:10.4314/tjpr.v13i7.20

The Plant List (2013). Royal Botanic Gardens and Missouri Botanical Garden. Kew and St. Louis. Version 1.1. Available at: http://www.theplantlist.org/(Accessed March 11, 2017).

Tian, X., Guo, S., Zhang, S., Li, P., Wang, T., Ho, C. T., et al. (2019). Chemical Characterization of Main Bioactive Constituents in Paeonia ostii Seed Meal and GC-MS Analysis of Seed Oil. J. Food Biochem. 44 (1), e13088. doi:10.1111/ jfbc. 13088

Tsai, P.-W., De Castro-Cruz, K. A., Shen, C.-C., Chiou, C.-T., and Ragasa, C. Y. (2013). Chemical Constituents of Artocarpus camansi. Pharmacognosy J. 5 (2), 80-82. doi:10.1016/j.phcgj.2012.06.001 van Duong, N. (1993). Medicinal Plants of Vietnam. (Cambodia and Laos: Nguyen Van Duong).

van Valkenburg, J. L. C. H., and Bunyapraphatsara, N. (2001). Plant Resources of South-East Asia (PROSEA) No 12 (2), Medicinal and Poisonous Plants 2. Leiden: Backhuys Publishers.

Wiart, C., Mogana, S., Khalifah, S., Mahan, M., Ismail, S., Buckle, M., et al. (2004). Antimicrobial Screening of Plants Used for Traditional Medicine in the State of Perak, Peninsular Malaysia. Fitoterapia 75 (1), 68-73. doi:10.1016/ j.fitote.2003.07.013

Win, N. N., Ito, T., IsmailKodama, T., Kodama, Y. Y., Tanaka, M., et al. (2015). Picrajavanicins A-G, Quassinoids from Picrasma javanica Collected in Myanmar. J. Nat. Prod. 78 (12), 3024-3030. doi:10.1021/acs.jnatprod.5b00824

Woo, K. W., Cha, J. M., Choi, S. U., and Lee, K. R. (2016). A New Triterpene Glycoside from the Stems of Lagerstroemia indica. Arch. Pharm. Res. 39 (5), 631-635. doi:10.1007/s12272-016-0746-4

World Health Organization (2020b). Antimicrobial Resistance. Available at: https://www.who.int/en/news-room/fact-sheets/detail/antimicrobial-resistance (Accessed September 13, 2021).

World Health Organization (2020a). The Top 10 Causes of Death. Available at: https://www.who.int/news-room/fact-sheets/detail/the-top-10-causes-of-death (Accessed September 13, 2021).

Wu, X., Alam, M. Z., Feng, L., Tsutsumi, L. S., Sun, D., and Hurdle, J. G. (2013). Prospects for Flavonoid and Related Phytochemicals as Nature-Inspired Treatments for Clostridium difficile Infection. J. Appl. Microbiol. 116 (1), 23-31. doi:10.1111/jam.12344

$\mathrm{Xu}, \mathrm{K}$. , and Jiang, B. (2017). Analysis of Mucosa-Associated Microbiota in Colorectal Cancer. Med. Sci. Monit. 23, 4422-4430. doi:10.12659/msm.904220

Yang, G. X., Zhang, R. Z., Lou, B., Cheng, K. J., Xiong, J., and Hu, J. F. (2014). Chemical Constituents from Melastoma dodecandrum and Their Inhibitory Activity on Interleukin-8 Production in HT-29 Cells. Nat. Prod. Res. 28 (17), 1383-1387. doi:10.1080/14786419.2014.903480

Zawawi, N. K., Ahmat, N., Mazatulikhma, M. Z., Shafiq, R. M., Wahid, N. H., and Sufian, A. S. (2012). Bioactive Oligostilbenoids from Shorea maxwelliana King and Their Chemotaxonomic Significance. Nat. Prod. Res. 27 (17), 1589-1593. doi:10.1080/14786419.2012.730047

Zeng, X. H., Li, Y. H., Wu, S. S., Hao, R. L., Li, H., Ni, H., et al. (2013). New and Highly Efficient Column Chromatographic Extraction and Simple Purification of Camptothecin from Camptotheca acuminata and Nothapodytes pittosporoides. Phytochem. Anal. 24 (6), 623-630. doi:10.1002/pca.2441

Conflict of Interest: The authors declare that the research was conducted in the absence of any commercial or financial relationships that could be construed as a potential conflict of interest.

Publisher's Note: All claims expressed in this article are solely those of the authors and do not necessarily represent those of their affiliated organizations or those of the publisher, the editors, and the reviewers. Any product that may be evaluated in this article or claim that may be made by its manufacturer is not guaranteed or endorsed by the publisher.

Copyright (c) 2021 Kudera, Fiserova, Korytakova, Doskocil, Salmonova, Tulin, Nguon, Bande and Kokoska. This is an open-access article distributed under the terms of the Creative Commons Attribution License (CC BY). The use, distribution or reproduction in other forums is permitted, provided the original author $(s)$ and the copyright owner(s) are credited and that the original publication in this journal is cited, in accordance with accepted academic practice. No use, distribution or reproduction is permitted which does not comply with these terms. 